\title{
Plutonium Disproportionation Reactions: Some Unresolved Problems
}

G. L. Silver

\section{MOUND LABORATORY}

Miamisburg, Ohio operated by MONSANTO RESEARCH CORPORATION a subsidiary of Monsanto Company for the

\section{U. S. ATOMIC ENERGY COMMISSION}

U. S. Government Contract No. AT-33-1-GEN-53 


\section{DISCLAIMER}

This report was prepared as an account of work sponsored by an agency of the United States Government. Neither the United States Government nor any agency Thereof, nor any of their employees, makes any warranty, express or implied, or assumes any legal liability or responsibility for the accuracy, completeness, or usefulness of any information, apparatus, product, or process disclosed, or represents that its use would not infringe privately owned rights. Reference herein to any specific commercial product, process, or service by trade name, trademark, manufacturer, or otherwise does not necessarily constitute or imply its endorsement, recommendation, or favoring by the United States Government or any agency thereof. The views and opinions of authors expressed herein do not necessarily state or reflect those of the United States Government or any agency thereof. 


\section{DISCLAIMER}

Portions of this document may be illegible in electronic image products. Images are produced from the best available original document. 
MLM-1807 (draft)

TI $D-4500$

UC -4

\title{
Plutonium Disproportionation Reactions: Some Unresolved Problems
}

\author{
G. L. Silver
}

Issued: May 10, 1971

\section{LEGAL NOTICE}

This report wos prepared as on account of work sponsared by the United States Government Neither the United Siates nor the United States Atomic Energy Com mission, nor any of their employees, nor any of their contractors, subcontractors, or their employees, mokes ony warranty express or implied, or assumes any legol liability or responsibility for the occurocy, completeness or usefulness of any information, apparatus, product or process disclosed, or represents that its use would not infringe privotely owned rights

$$
\begin{gathered}
\text { PRINTED IN THE UNITED STATES OF AMERICA } \\
\text { Available from } \\
\text { National Technical Information Service } \\
\text { U } 5 \text { Department of Commerce } \\
5285 \text { Port Royal Road } \\
\text { Springfield Virginia } 22151 \\
\text { Price Printed Copy } \$ 300 \text { Microfiche } \$ 095
\end{gathered}
$$

\section{MONSANTO RESEARCH CORPORATION}

A Subsidiary of Monsanto Company

\section{MOUND LABORATORY}

Miamisburg, Ohıo

45342

operated for

\section{UNITED STATES ATOMIC ENERGY COMMISSION}

US Government Contract No AT-33-1-GEN-53 


\begin{abstract}
The preparation of a predominance region diagram for aqueous plutonium solutions is discussed, and conditions for the equality of the concentrations of three plutonium species are suggested. Other methods of determining the values of variable stoichiometry coefficients for tetravalent and pentavalent plutonium are proposed, as are methods for ascertaining plutonium valence state distributions in dilute acids without recourse to lengthy analytical procedures. These methods involve measurement of two solution variables such as acidity and redox potential or fraction of one plutonium species, and are illustrated with computer programs by Carl Wendling. A method of ascertaining the acidity of maximum stability of pentavalent plutonium is proposed, and the effect of temperature upon the stability of the pentavalent plutonium ion is suggested.
\end{abstract}




\section{INTRODUCTION}

The chemistry of plutonium is rendered colorful and interesting by the diversity of oxidation states and ionic species which may coexist in aqueous solutions of this element. Although predominance region diagrams are frequently used to illuminate chemical behavior and although a predominance region diagram for an element capable of existing in four oxidation states might be useful, discussions of such diagrams for plutonium are rare. It is part of the purpose of this report to propose a method of preparing a plutonium predominance region diagram. It is also a purpose of this report to present some questions about the chemistry of plutonium which were not satisfactorily answerable by plutonium literature up to 1970. Accompanying the questions are some proposed answers which hopefully will stimulate some interest in these infrequently considered aspects of plutonium chemistry.

1. Question: Although many books dealing with the chemistry of plutonium have appeared, relatively few of them contain predominance region diagrams. Might the concept of including all plutonium valence states in disproportionation stoichiometries be useful in preparing a plutonium predominance region diagram?

Probably the most desirable method of preparing a plutonium predominance region diagram involves direct use of expressions for potentials of the various plutonium couples.1 A more informal method involves solving Equations (1) and (2) for a variety of acidity values and average oxidation numbers and ascertaining by inspection which plutonium species predominates. ${ }^{3}$

$$
\begin{aligned}
& 0=\frac{K_{2}^{2} Y^{3} H^{4}}{K_{1} Z^{2}}+\frac{K_{2} Y^{2} H^{4}}{K_{1} Z}+Y-(1-Z) \\
& \frac{3 W+4 X+5 Y+6 Z}{W+X+Y+Z}=N
\end{aligned}
$$

In Equations (1) and (2) the symbols $\mathrm{W}, \mathrm{X}, \mathrm{Y}, \mathrm{Z}, \mathrm{H}, \mathrm{N}, \mathrm{K}_{1}$, and $\mathrm{Ke}$ represent, respectively, equilibrium concentrations of $\mathrm{Pu}(\mathrm{III}), \mathrm{Pu}(\mathrm{IV}), \mathrm{Pu}(\mathrm{V})$, $\mathrm{Pu}(\mathrm{VI})$, acidity, average oxidation number, and the values of the equilibrium constants for Equations (3) and (4), respectively: 


$$
\begin{aligned}
& \mathrm{K}_{1}=\frac{W \mathrm{WH}^{4}}{\mathrm{X}^{2}}, \\
& \mathrm{~K}_{2}=\frac{\mathrm{WZ}}{\mathrm{XY}} .
\end{aligned}
$$

Since plutonium species fractions and ratios can be obtained from Equations (1) and (2), an approximate predominance region diagram may be constructed. Such approximate diagrams are shown in Figures 1 and 2 and were prepared with the aid of the data in Table 1, Reference 3. Complicating phenomena such as hydrolysis were neglected in preparing Figures 1 and 2.

2. Question: Many interesting and curious aspects of plutonium chemistry remain uninvestigated. One of these is the "multiple point problem", i.e., the problem of ascertaining those points where the concentrations of two or more plutonium species are identical. Does plutonium exhibit a quadruple point and a triple point? If so, where are these points located in the predominance region diagram?

By quadruple point is meant that point where the concentrations of four plutonium species are equal, $W=X=Y=Z$. Since the value of Equation (4) is not unity, plutonium cannot exhibit a quadruple point in perchloric acid. In another medium, such as nitric acid or nitric acid containing sodium nitrate, however, it might be possible to observe a quadruple point in the sums of all species in a given oxidation state.

Plutonium exhibits many double points. Some double points may be found by examining the diagrams in Reference 2. In strong acid, pentavalent plutonium may be expected to partition into $\mathrm{Pu}(\mathrm{VI})$ and largely undisproportionated $\mathrm{Pu}(\mathrm{IV})$ so that by extrapolation a double point is approached. Presumably this double point would be approached more quickly in sulfuric than in perchloric acid.

The problem of triple points is more interesting. For a triple point to occur the concentrations of any three plutonium species must be equal. Two triple points occur at the intersections of the (III), (IV), (VI) and (III), (V), (VI) regions in Figure 2. Two other triple points also occur. For example, when $W=X=Y$, the (III), (IV), (V) triple point occurs. Since, in this case, by application of Equation (4)

$$
\mathrm{Z}=\mathrm{K}_{\mathrm{z}} \mathrm{Y} \text {, }
$$

it follows from the first term in Equation (1) that

$$
\mathrm{X}=\frac{\mathrm{K}_{2} \mathrm{Y}^{2}(\mathrm{H})^{4}}{\mathrm{~K}_{1} \mathrm{~K}_{\mathrm{g}} \mathrm{Y}}=\mathrm{Y}
$$


or

$$
\mathrm{H}=\left(\mathrm{K}_{1}\right)^{\frac{1}{4}}=0.16 \underline{\mathrm{M}} \text {. }
$$

From Equations (2) and (5)

$$
\frac{12+6 \mathrm{~K}_{2}}{\mathrm{~K}_{2}+3}=\mathrm{N}=5.62 \text {. }
$$

This triple point is marked $\mathrm{W}=\mathrm{X}=\mathrm{Y}$ on Figure 2. Table 1 summarizes some pertinent triple points for plutonium.

In plutonium solutions of low acidity, considerable hydrolysis of the tetravalent $\mathrm{Pu}(\mathrm{IV})$ cation occurs. When such hydrolysis of plutonium cations occurs, it is convenient to speak of a triple point as either that point where the concentrations of three ionic species are equivalent, or that point where the concentrations of three oxidation states are equivalent. For the (III), (IV), (VI) triple point which occurs near $0.3 \mathrm{M}$ acid, only tetravalent plutonium will be appreciably hydrolyzed. The point where the concentrations of trivalent, hexavalent, and tetravalent plutonium are equivalent $\left[\mathrm{Pu}^{3+}=\mathrm{PuO}_{2}^{++}=\mathrm{Pu}^{4+}\left(+\mathrm{PuOH}^{3+}\right)\right]$ may be found by use of Equations (8), (9), and (4). Hydrolysis decreases the acidity at which this (III), (IV), (VI) triple point occurs:

$$
\begin{aligned}
& \mathrm{X}+\mathrm{HOH}=\mathrm{XOH}+\mathrm{H}, \\
& \mathrm{X}=\frac{\mathrm{K}_{2} \mathrm{Y}^{2} \mathrm{H}^{4}}{\mathrm{~K}_{\mathrm{I}} \mathrm{Z}} .
\end{aligned}
$$

Table 2 illustrates the behavior of plutonium in the neighborhood of some triple points.

3. Question: Historically, Equations (10), (11), and (12) have been used to represent disproportionation reactions of plutonium:

$$
\begin{aligned}
& 3 \mathrm{Pu}(\mathrm{IV})=\mathrm{Pu}(\mathrm{III})+2 \mathrm{Pu}(\mathrm{VI}) . \\
& 2 \mathrm{Pu}(\mathrm{V})=\mathrm{Pu}(\mathrm{IV})+\mathrm{Pu}(\mathrm{VI}) . \\
& 3 \mathrm{Pu}(\mathrm{V})=\mathrm{Pu}(\mathrm{III})+2 \mathrm{Pu}(\mathrm{VI}) .
\end{aligned}
$$

It has been proposed that all common oxidation states of plutonium be included in each equation. Three methods have been proposed for this inclusion: a method based upon electromotive force values, a method based upon free energy values, and a method based upon equilibrium constants..$^{2-4}$ Is another method available? 
As representations of plutonium disproportionation reactions, Equations (10), (11), and (12) violate the principle of conservation of mass since they do not include all products which experiment has shown to derive from pentavalent and tetravalent plutonium ions. Another method of finding disproportionation stoichiometries which include all common oxidation states of plutonium is based upon a method of random guessing and may be illustrated with tetravalent plutonium. In plutonium solutions at equilibrium, the (V), (VI) and (III), (VI) oxidation-reduction couples are also at equilibrium.

This may be expressed as

$\mathrm{E}^{\mathrm{O}} \mathrm{Y,Z}+0.05916 \log \left(\frac{\mathrm{Z}}{\mathrm{Y}}\right)=\mathrm{E}_{\mathrm{W}, \mathrm{Z}}^{\mathrm{O}}+\frac{0.05916}{3} \log \frac{\mathrm{ZH}^{4}}{\mathrm{~W}}$,

which may be solved for $\log \left(\frac{Z}{W}\right)$ by

$\log \frac{Z}{W}=\frac{3\left(E_{Y, Z^{O}}^{-E^{O}}{ }_{W, Z}+0.05916 \log Z / Y\right)}{0.05916}-4 \log \mathrm{H}$.

Substituting values ${ }^{5,6}$ for perchloric acid yields

$\log \left(\frac{Z}{W}\right)=3 \frac{(-0.1064+0.05916 \log M)}{0.05916}-4 \log \mathrm{H}$

At a given acidity, nothing is known on an a priori basis about the correct value of either $Z / Y$ or $Z / W$. The value of $Z / Y$ may be guessed, however, to obtain a corresponding value for $Z / W$. Using, for example, a ratio of $\mathrm{Z} / \mathrm{Y}$ of unity leads to a value of $4.10^{-6}$ for the ratio $\mathrm{Z} / \mathrm{W}$ in one molar acid. In Pu(IV) solutions, charge conservation is maintained:

$W=Y+2 Z$.

When $\mathrm{Z}=\mathrm{Y}, \mathrm{Z}=1 / 3 \mathrm{~W}$.

But this is impossible since $\mathrm{Z}=4 \cdot 10^{-6} \mathrm{~W}$. Therefore, the ratio $\mathrm{Z} / \mathrm{Y}=1$ cannot be correct for tetravalent plutonium solutions in molar perchloric acid. Try $Z / Y=50$. Then Equation (15) shows that $Z=0.502 \mathrm{~W}$. Equation (16) shows that when $Z / Y=50$, then $Z=0.495 \mathrm{~W}$. The agreement between Equations (15) and (16) is much better when $Z / Y=50$ than when $\mathrm{Z} / \mathrm{Y}=1$. Hence, the equilibrium ratio of $\mathrm{Pu}(\mathrm{VI})$ to $\mathrm{Pu}(\mathrm{V})$ in molar $\mathrm{HClO}_{4}$ solutions of originally pure $\mathrm{Pu}(\mathrm{IV})$ is closer to 50 than to unity. This guessing procedure may be pursued to any degree of accuracy and the results used to ascertain disproportionation stoichiometries. In a variation on this same theme, values of $W, Y$, and $Z$ may be inserted into

$$
\frac{3 W+5 Y+6 Z}{W+Y+Z}=N
$$


When the value of Equation (17) is 4.00, the correct interrelationship of disproportionation products (stoichiometry) has been ascertained.

4. Question: While methods presented heretofore for determining valence state distributions for solutions derived from $\mathrm{Pu}(\mathrm{IV})$ or $\mathrm{Pu}(\mathrm{V})$ suggest that the general problem of plutonium valence state distribution may at least be solvable, these methods seem superficial. Are more elegant, more penetrating, and more accurate methods of solving plutonium equilibrium problems available?

Whether or not the concept of including al1 plutonium oxidation states in approaches to plutonium equilibrium problems will prove worthy and useful has not been ascertained. At least up to 1970, the concept seemed to have limited appeal. If the concept proves worthy, more elegant, more practical, and more accurate approaches to plutonium equilibrium problems may be expected. Rudimentary approaches will be replaced by more helpful and accurate approaches.

It is a belief which is common $1 \mathrm{y}$ held, but uncommonly applied, that in a mixture of chemical species equilibrium is characterized by the minimization of free energy. It would, therefore, seem that the general plutonium equilibrium problem could be solved by the Simplex method. This method has been little used in chemical applications of the solution equilibrium type, perhaps because little of the literature describing the application of Simplex computations is comfortably readable. The application of the Simplex method to plutonium equilibria in a lucid and illuminating matter is an unsolved problem in plutonium chemistry and is an opportunity for study which hopefully will be exploited by chemists in a clear and unassuming style. An approach much less sophisticated than the Simplex method is adapted here.

The chemical potential or free energy per mole of a chemical species may be taken as

$$
\mu=\mu^{\circ}+R T \ln (a)
$$

where "a" is the activity of the species and $\mu^{\circ}$ is the standard chemical potential. For $\mathrm{Pu}^{3+}, \mu^{\circ}$ may be taken for illustrative purposes ${ }^{5}$ as $-135.8 \mathrm{kca} 1 / \mathrm{mole}$. If $\mathrm{M}$ is the ratio of $\mathrm{PuO}_{2}{ }^{+}$to $\mathrm{PuO}_{2}{ }^{+}, \mathrm{Y}$ the concentration of $\mathrm{PuO}^{+}$, and activities and concentrations presumed identical, then the chemical potential of $\mathrm{Pu}^{3+}$ may be expressed as (in $\mathrm{kcal} / \mathrm{mole}$ )

$$
\mu_{W}=-135.8+0.5921[\ln (\mathrm{Y}+2 \mathrm{MY})] \text {. }
$$

When $\mathrm{Pu}^{3+}$ is generated from $\mathrm{Pu}^{4}+$, as occurs in the disproportionation of $\mathrm{Pu}^{4+}$, then the formation free energy of $\mathrm{Pu}^{3+}$ from $\mathrm{Pu}^{4+}$

$$
\mathrm{Pu}^{4+}+\frac{1}{2} \mathrm{H}_{2}=\mathrm{Pu}^{3+}+\mathrm{H}^{+},
$$

may be taken as 


$$
\mu_{\mathrm{k}}=-135.8+0.5921 \ln [(\mathrm{Y}+2 \mathrm{MY})(\mathrm{H})],
$$

or, since $(\mathrm{Y}+2 \mathrm{MY})$ moles of $\mathrm{Pu}^{3+}$ are formed, then the total free energy of formation of the equilibrium amount of $\mathrm{Pu}^{3+}$ is

$$
\mathrm{F}_{\mathrm{w}}=(\mathrm{Y}+2 \mathrm{MY})[-135.8+\mathrm{RT} \ln (\mathrm{Y}+2 \mathrm{MY})(\mathrm{H})] \text {. }
$$

With the free energy value of $\mathrm{Pu}^{3+}$ from Reference 5, free energies of other plutonium species may be found from the potential data in Cleveland. ${ }^{6}$ These are listed in Table 3.

The disproportionation of tetravalent plutonium generates hydrogen ions. The total generated is $(4 \mathrm{Y}+4 \mathrm{MY})$. The free energy associated with this generation is ( $4 \mathrm{Y}+4 \mathrm{MY}) \mathrm{RT} 1 \mathrm{nH}$, and account is taken of this by including $\mathrm{H}$, the equilibrium acidity, in the expressions in Table 3. The free energy change associated with the consumption of water is $\mathrm{Y}(-113.38 \mathrm{M}$ 113.38).

In order for the equilibrium condition to be satisfied, the sum of the free energies of all of the species in the chemical reaction should be minimized. In the case of plutonium, however, the disproportionation reaction involves solvent, and this must be considered in the free energy accounting. Hence, the sum of all of the terms in Table 3 minus the free energy change associated with the destruction of water given above is the expression whose value is to be minimized. This may be done by assuming a value of $\mathrm{Y}$ and allowing the value of $\mathrm{M}$ to vary over a preselected range. The sum of the terms in Table 3 minus the free energy term associated with the destruction of water should then show a relative minimum. This may be illustrated with an example.

Suppose it is otherwise known that the equilibrium concentration of pentavalent plutonium in a 0.2 M $\mathrm{HClO}_{4}$ solution of plutonium, originally al1 in the tetravalent state, is betwêen $1 \%$ and $10 \%$ of the total plutonium. The problem is to obtain a better estimate, using free energy terms, of the equilibrium concentration of $\mathrm{PuO}_{2}{ }^{+}$. Table 4 shows the behavior of the function $\Sigma F_{p u}-F_{H_{2}} \circ$ for some ${ }^{2}$ guessed $Y$ and $M$ values which satisfy the expression $\stackrel{p}{1}-\left(3 M^{4}+2\right) Y>0$.

In this technique, $\mathrm{Y}$ becomes an arbitrarily assigned "equilibrium" concentration of $\mathrm{PuO}^{+}$. The combination of $\mathrm{Y}$ and $\mathrm{M}$ which is the "best guess", i.e., closest to the true values of $\mathrm{Y}$ and $\mathrm{M}$ in $0.2 \mathrm{M}$ acid, may be found when the term $\Sigma F_{p u}-F_{H_{2}}$ o exhibits both a relative minimum (minimum with respect to other values for a fixed $\mathrm{Y}$ ) and an absolute minimum (i.e., lowest value for any combination of $M$ and $Y$ ). Table 4 shows that relative minima of the free energy function are obtained for $\mathrm{Y}=0.07, \mathrm{M}=3 ; \mathrm{Y}=0.03, \mathrm{M}=8$; and $\mathrm{Y}=0.01, \mathrm{M}=26$, but that the sum of the free energy terms is lowest for $\mathrm{Y}=0.03, \mathrm{M}=8$. Hence, within the limited accuracy of Table 4 and the limited selection of guesses for the value of $\mathrm{Y}$, the equilibrium concentration of $\mathrm{PuO}_{2}+$ in a $0.2 \mathrm{M}$ $\mathrm{HClO}_{4}$ solution of $\mathrm{Pu}(\mathrm{IV})$ is $3 \%$ and the $\mathrm{PuO}_{2}{ }^{++} / \mathrm{PuO}_{2}{ }^{+}$equilibrium ratio is 8. Elsewhere ${ }^{3}$ it is shown that the relative equilibrium concentra- 
tion of $\mathrm{PuO}_{2}{ }^{+}$in such a plutonium solution is closer to $4 \%$, and $\mathrm{M}$ is close to 5.7. For practical applications, this procedure is not satisfactory, since values of $\mathrm{PuO}_{z}{ }^{+}$and $M$ which lead to acceptable behavior of the free energy terms might be obtained only after very long periods of guessing. The principal of the maximization of entropy in plutonium solutions could also be applied to this problem although reliable entropy values for plutonium species are not easily obtained. Doubtless the best approach would be the application of the Simplex technique to the minimization of the free energy or the maximization of entropy, and these remain unsolved problems in plutonium chemistry.

These problems are complicated by the lack of reliable free energies and entropies of actinide ions. Thus, Seaborg ${ }^{7}$ gives values of the free energies of plutony 1 ions which differ considerably from those 1 isted in Table 3. Seaborg's values, if they are correct, would invalidate Table 4, and any conclusions drawn from this table. The differences in Seaborg's values and the values in Table 3 may be due to the free energy of formation of water.

5. Question: What is the relationship between average oxidation number and redox potential?

Unfortunately, there does not seem to be a simple connection between the average oxidation number and the redox potential of a plutonium solution; at least, a simple relationship has not yet been suggested. For a given average oxidation number, the redox potential depends upon the acidity and the magnitude of the plutonium alpha factors. The latter factors depend upon the nature of the plutonium solution. i.e., whether it is a nitric acid or a citric acid solution, for example. Where AW, AX, AY, and $\mathrm{AZ}$ are the alpha factors for $\mathrm{Pu}(\mathrm{III}), \mathrm{Pu}(\mathrm{IV}), \mathrm{Pu}(\mathrm{V})$, and $\mathrm{Pu}(\mathrm{VI})$, respectively, the average oxidation number $\mathrm{N}$ may be ascertained from a knowledge of $\mathrm{H}$ and $\mathrm{M}$ and application of Equation (20):

$$
\frac{(A W) K_{2}^{2} H^{4}(3-N)}{K_{1} M^{2}}+\frac{(A X) K_{2} H^{4}(4-N)}{K_{1} M}+(A Y)(5-N)+(A Z)(M)(6-N)=0
$$

It is to be remarked that the application of this equation to the computer program in Reference 2 allows the determination of the distribution of plutonium valence states in dilute acid if the acidity of the solution is known and if the potential (vs N.H.E.) of the solution is known. The value of $M$ may be calculated from the potential. Application of this concept might eliminate frequently tedious plutonium valence state determinations in manufacturing processes. Two possible applications are suggested in the Appendix and illustrated with computer programs by Car1 Wendling.

6. Question: Many problems associated with the chemistry of the disproportionation reactions of plutonium remain unresolved. Although 
investigations into this area have ceased to be popular and although disproportionation matters are considered settled, in fact this area still presents much opportunity for exploration. What are some other unresolved problems in the chemistry of plutonium disproportionation reactions?

As is we11 illustrated by Cleveland ${ }^{6}$ and Jones and Choppin, ${ }^{8}$ there is presently no general agreement on redox potential values for the various plutonium couples. This is a rather fundamental unresolved problem since disagreement over such values amounts to disagreement over the behavior of plutonium. Since there is disagreement over formal potential values, it is unlikely that there will be rapid agreement over standard potential values which are of considerable theoretical interest. Moreover, there is reason to believe that values currently accepted as correct formal potential values may have been ascertained using concepts which are at best only approximations.

The potential of the $\mathrm{Pu}$ (III), $\mathrm{Pu}(\mathrm{IV})$ couple is variously given 6.8 as 0.9818 or 0.9819 . Probably either value is acceptable, since experimental errors in the determination of these values are likely as large as their disagreement. Of greater interest is the accepted value of 1.0228 for the Pu(III), Pu(VI) couple. This value seems to have been calculated from directly measured potentials of the $\mathrm{Pu}($ III), $\mathrm{Pu}(\mathrm{IV})$ and $\mathrm{Pu}(\mathrm{V})$, $\mathrm{Pu}(\mathrm{IV})$ couples and "the $\mathrm{Pu}^{4+}$ disproportionation equilibrium quotient".9 The problem, however, is that this disproportionation equilibrium quotient seems to have been obtained from the universally accepted equation,

$$
3 \mathrm{Pu}(\mathrm{IV})=2 \mathrm{Pu}(\mathrm{III})+\mathrm{Pu}(\mathrm{VI})
$$

- representing the disproportionation of tetravalent plutonium. But this equation is inaccurate because it omits pentavalent plutonium. Hence, the "equilibrium quotient" is only approximate, and the number 1.0228 is, therefore, also approximate. Silver has used this number to show that the behavior of tetravalent plutonium in dilute acid differs significant1y from the behavior predicted by Equation 12. Hence, the results of Silver cannot be more than approximate, since 1.0228 was based upon a fallacious assumption. There follow arguments which are circular, where one argument (i.e., the notions of Silver) is used to show that a previous argument (i.e., Equation 12) is only an approximation, but which itself is based upon the information not available except through that approximation, and therefore is only another approximation. In other words, the number 1.0228 was derived using Equation 12, and then 1.0228 was used to show that Equation (12) is false. How can this circularity be avoided? Historical precedent suggests it may be avoided by insisting it does not exist, and that by virtue of tradition, Equation 12 shall be correct. Another exit is to reexamine the disproportionation issue in a critical manner. Hence, an unresolved problem in the chemistry of the disproportionation reactions of plutonium is the lack of an accurate picture of the chemistry of the disproportionation reactions of plutonium. 
Closely associated with the uncertainties surrounding standard potential values for plutonium are the uncertainties surrounding equilibrium constants for plutonium reactions. For example, the value of Equation (4) has been taken as 13.1,6 $12.8,1014.4,1^{10}$ and $10.7 .1^{1}$ The value of this equation is dependent upon solution acidity since $\mathrm{Pu}^{4+}$ is subject to extensive hydrolysis. If the value of Equation (4) is 12.8 when Equation (4) is expressed in terms of total concentrations, then the value of this equation expressed in terms of free ions should be about 13.2 in $\underline{M}$ perchloric acid since

$$
\mathrm{Pu}(\mathrm{IV})=\mathrm{Pu}^{4+}+\mathrm{PuOH}^{3+}=\mathrm{Pu}^{4+}\left[1+\frac{0.03}{\mathrm{H}}\right] .
$$

If the ionic product is taken as 13.2, the value of Equation (4) should then be about 10.2 in $0.1 \mathrm{M}$ perchloric acid. This compares we11 with the experimentally determined value of about 10.7 in this acidity. ${ }^{12}$ Similarly, in $0.052 \mathrm{M}$ acid, the value of Equation (4) is calculated to be about 8.4 , which compares well with the observed value ${ }^{13}$ of about 8 . The ionic product for Equation (3) is similarly calculated as $10^{-3.157}$ and for the equilibrium statement for the first kinetic step in the disproportionation of pentavalent plutonium $(2 \mathrm{Y}=\mathrm{X}+\mathrm{Z}): 10^{4.277}$. These latter values must be only approximate, however, since they are based upon the estimated value of the potential of one "plutonium plutonyl" couple.

A detailed analysis of the effect of ionic strength upon plutonium equilibria remains an unsolved problem in plutonium chemistry.

7. Question: Neglecting hydrolysis, how does the potential of a solution of tetravalent or pentavalent plutonium vary with acidity?

An explicit relation between solution potential and acidity for tetravalent and pentavalent plutonium in dilute acids has never been proposed, and this remains an unresolved problem in plutonium chemistry. The potential behavior of tetravalent and pentavalent plutonium solutions in extremes of acidity, i.e., rather dilute and rather concentrated, may be surmised in at least two ways. For example, pentavalent plutonium in rather strong acid solutions disproportionates to yield primarily tetravalent and hexavalent plutonium. The potential of the Pu(IV)-Pu(VI) couple varies as the square of the acidity, so that the potential of a solution containing originally only pentavalent plutonium will also vary with the square of the acid concentration in solutions of strong acid (e.g., $\mathrm{pH}<0$ ). In very dilute acid solutions (e.g., $\mathrm{pH}>2$ ) the disproportionation of pentavalent plutonium yields primarily trivalent and hexavalent plutonium in a ratio of 0.5 . Hence, such solutions should yield potential behavior which varies with the $4 / 3$ power of the acidity and differs from the formal potential of the Pu(III)-Pu(VI) couple by a constant. The potential behavior of solutions of intermediate acidity is more complex. 
The potential acidity behavior of solutions of tetravalent plutonium may be guessed by use of Equation (17) of Reference 2 which is reproduced below:

$$
12.67+4 \ln (H)=2 \ln (M)+\ln (1+2 M),
$$

where $M$ is the $\mathrm{Pu}(\mathrm{VI}) / \mathrm{Pu}(\mathrm{V})$ ratio. When $\mathrm{H}$ (the equilibrium acidity) is very small, $M$ must also be small. If $M$ is small, the term $(1+2 M)$ will be nearly unity. Since the logarithm of unity is zero, the value of the potential must vary with the square of the acidity. When $\mathrm{H}$ is large, the term $(1+2 M) \approx 2 M$, so that the value of potential must vary as the $4 / 3$ power of acidity. In solutions of intermediate acidity (e.g., pH 1), the behavior of potential with acidity is more complex and assumes a value between 1.33 and 2.00 . To a limited extent, the acidity dependence of the potential may be interpreted as the hydrogen ion dependence of the particular plutonium disproportionation reaction. For all acidity values, it may be said that the hydrogen ion dependence of a plutonium disporportionation reaction is fourth order with respect to plutonium oxygenyl cations.

Figure 3 presents a predominance region diagram for plutonium in which has been sketched the potential paths of tetravalent and pentavalent plutonium solutions, derived with the aid of Equation 22 and Equation 23 . The constants which appear in these equations are discussed in Question 6. These equations and the potentials derived from them neglect complicating phenomena such as hydrolysis. The constants lead to the scheme of "standard" potential values shown below. These "standard" values correct for the formation of $\mathrm{PuOH}^{3+}$ only and are presented on ly as an illustration of how such a scheme might be prepared and are not suggested as substitutes for the more popular values currently used. It is to be remarked that values which do not involve tetravalent plutonium remain identical to those presented by Cleveland. ${ }^{6}$ For reasons outlined above, these values are approximate. An analysis of the degree to which such values might be approximate remains an unresolved problem in plutonium chemistry.

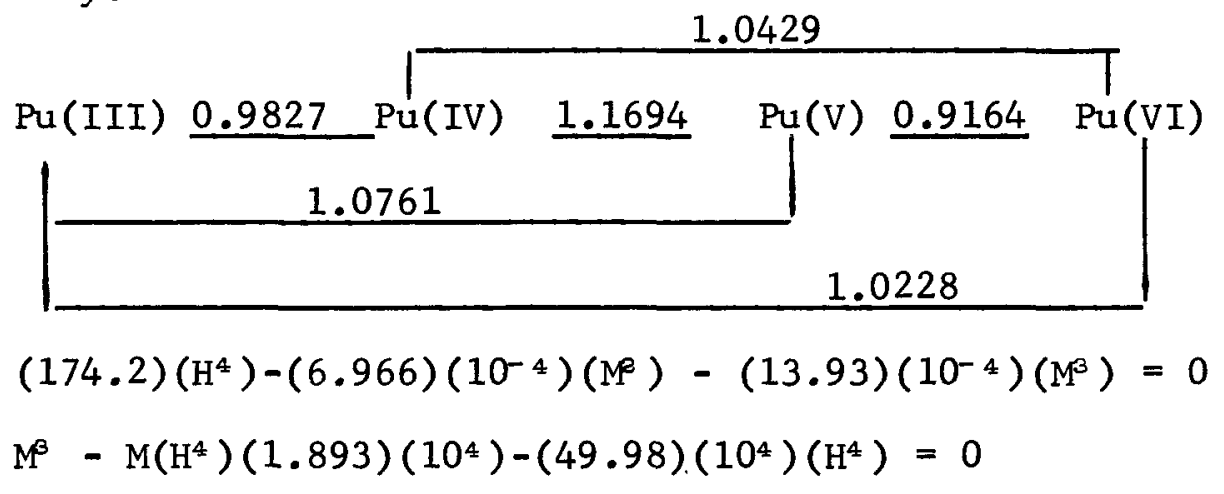


8. Question: How do plutonium "oxistatic" potentials vary with acidity?

By the term "oxistatic" potential is meant the potential for a plutonium solution of constant average oxidation number. These potentials may be obtained by solving Equation (24) for selected values of the equilibrium acidity. The behavior of the ratio $\mathrm{Pu}(\mathrm{VI}) / \mathrm{Pu}(\mathrm{V})(=\mathrm{M})$ is plotted in $\log$ arithmic form in Figure 4 for selected values of $\mathrm{N}$, the average oxidation number. For $\mathrm{N}=4.0$ and $\mathrm{N}=5.0$, the slopes of the lines are equal near $M=\left(K_{2}\right)^{\frac{1}{2}}$ and have the approximate magnitude -1.39 .

$$
\begin{aligned}
& (2.501)\left(10^{5}\right)(3-N)\left(H^{4}\right)+(1.895)\left(10^{4}\right)(M)(4-N)\left(H^{4}\right) \\
& +\left(M^{8}\right)(5-N)+(6-N)\left(M^{3}\right)=0
\end{aligned}
$$

Question 8 illustrates one of many aspects of the general plutonium equilibrium problem which remain unresolved. Another one might be: How does the potential of a plutonium solution in which the fraction of oxygenyl cations is to be held constant vary with acidity? This problem might be solved by solving the equations

$$
\begin{aligned}
& W+X=1-F \\
& \frac{K_{2} X F}{1-f-X-K_{2} X}=\frac{X^{3} K_{1}-F H^{4}+F^{2} H^{4}+F X H^{4}}{F H^{4}+X H^{4}-H^{4}}
\end{aligned}
$$

where $F$ is the fraction of hexavalent and pentavalent plutonium taken together. These are only two examples of many interesting problems in disproportionation phenomena which remain unresolved.

In a well researched compilation of plutonium chemistry, Cleveland 3 observes the undesirability of ignoring a circumstance because the circumstance might be distasteful, and then proceeds to ignore the circumstance of three plutonium species in equations describing the disproportionation reactions of tetravalent and pentavalent plutonium. Of course, cleveland accords with the standard and taste of his time. Many years ago, M. Kasha suggested that matters need not be this way. In a discourse which proved to be ahead of his time, Kasha ${ }^{14}$ proposed that all oxidation states be included in a discussion of disproportionation equilibria, illustrating his point with sample calculations for Pu(V), and suggesting that the "... account given here will prove of value... in the interpretation of plutonium chemistry." It has not proven its true value because it has been ignored, not because of any inconsistency in the ideas of Kasha. Kasha's principal fault may have been that he was too perceptive. For example, he tacitly acknowledged the failure of mass conservation in the equation

$$
3 \mathrm{Pu}(\mathrm{IV})=2 \mathrm{Pu}(\mathrm{III})+\mathrm{Pu}(\mathrm{VI})
$$

by allowing mass to vary in computations of valence state distributions. His relationships for pentavalent plutonium (or for plutonium with other oxidation numbers) agree with values calculated elsewhere, ${ }^{4}$ which proves 
nothing but at least suggests that writing disproportionation equations which insist exclusively upon the generation of two plutonium oxidation states as products may not be wise and that no service has been rendered by ignoring the suggestions of Kasha. Why these suggestions have been ignored is an unresolved problem in plutonium chemistry.

9. Question: Computer programs ${ }^{3}$ in which plutonium valence state distributions may be calculated as a function of average oxidation number have been suggested. These programs suffer the shortcoming of containing within their statements a term for a species whose concentration becomes extremely small (regardless of average oxidation number) when the plutonium solution acidity is either very low or very large. How may this shortcoming be avoided?

The programs proposed ${ }^{3}$ require a computer determined solution for either pentavalent plutonium or tetravalent plutonium. When the acidity of a plutonium solution is high, for example 10M, when alpha factors are large, and when the value of the average oxidation number is close to 3.00 , the equilibrium concentration of pentavalent plutonium may be so small as to cause a computer "underflow". Likewise, in solutions of very low acidity, a computing machine may have difficulty with a program involving the solution of an equation for tetravalent plutonium. It would therefore be desirable to have a system of equations in which these problems do not arise.

Some of the programs proposed depend upon a statement for the average oxidation number:

$$
3 W(A W)+4 X\left[(A X)+\frac{(K H)}{H}\right]+5 Y(A Y)+6 Z(A Z)=N
$$

The coefficients $3,4,5$, and 6 for $W, X, Y$, and $Z$ may not be omitted from Equation 27 as stated, incorrectly, in Reference 3, page 43. Since the equation

$$
3 \mathrm{Pu}^{4+}+2 \mathrm{H}_{2} \mathrm{O}=2 \mathrm{Pu}^{3+}+\mathrm{PuO}_{2}^{++}+4 \mathrm{H}^{+}
$$

is not strictly valid for plutonium solutions (whereas the equilibrium constant expression for this equation does express a mathematical relationship which exists in plutonium solutions provided only real concentrations of $\mathrm{Pu}^{4+}, \mathrm{Pu}^{3+}$ and $\mathrm{PuO}_{2}{ }^{2+}$ are used, the sum of which may not be equal to the total quantity of plutonium present), it is convenient to use the expression

$$
\mathrm{K}_{1} \mathrm{~K}_{2}=\frac{\mathrm{W}^{2} \mathrm{ZH}^{4}}{\mathrm{X}^{3}}
$$

or

$$
X=\left[\frac{W^{2} Z^{4}}{K_{1} K_{2}}\right]^{\frac{1}{3}}
$$


Then, since

$$
(\mathrm{AW}) \mathrm{W}+(\mathrm{AX}+\mathrm{KH} / \mathrm{H}) \mathrm{X}+(\mathrm{AY}) \mathrm{Y}+(\mathrm{AZ}) \mathrm{Z}=1
$$

it follows that

$$
\mathrm{W}(\mathrm{AW})+\left(\mathrm{AX}+\frac{\mathrm{KH}}{\mathrm{H}}\right)\left(\frac{\mathrm{W}^{2} \mathrm{ZH}^{4}}{\mathrm{~K}_{1} \mathrm{~K}_{\mathrm{z}}}\right)^{\frac{1}{3}}+\frac{(\mathrm{AY})\left(\mathrm{K}_{1}\right)}{\mathrm{WH}^{4}}\left(\frac{\mathrm{W}^{2} \mathrm{ZH}^{4}}{\mathrm{~K}_{1} \mathrm{~K}_{2}}\right)^{\frac{2}{3}}+\mathrm{Z}(\mathrm{AZ})-1=0
$$

A computer program solving simultaneously Equation 27 and Equation 32 might be more practical than the program involving $Y$ and $Z$ proposed by Silver since in high acidities, which most chemists find practical, the values of $W$ and $Z$ are not likely to be so small as to cause computation difficulties. An exception to this, however, may occur in nitric acid solutions of plutonium-238, where, in solutions of greater than $1 \mathrm{M}$ nitric acid, both trivalent and pentavalent plutonium are likely to be scarce. Such solutions at steady state are likely to contain almost exclusively nitrate complexes of $\mathrm{Pu}(\mathrm{IV})$ and species of $\mathrm{Pu}(\mathrm{VI})$. In this circumstance, it might be best to replace Equation 32 with an equation involving only tetravalent and hexavalent plutonium as variables. A method of calculating plutonium oxidation state distributions which avoids these problems, and which does not require a computer so that it may be easily used on a moment's notice is an interesting and unresolved problem in plutonium chemistry.

10. Question: How might the stoichiometry of plutonium disproportionation reactions change with temperature?

The stoichiometry of disproportionation of pentavalent plutonium may be used to suggest an answer to this question. Cleveland ${ }^{6}$ has cited the behavior of potentials of plutonium couples as a function of temperature for IM hydrochloric acid solutions. From these data and the data which are 1isted in Appendix II, the answer to the above question may be guessed. In Table 5 are listed some approximate stoichiometries for $\mathrm{Pu}(\mathrm{V})$ in $1 \mathrm{M}$ hydrochloric acid.

Table 5 allows the preparation of a diagram such as shown in Figure 5 in which the proposed free energy change for the disproportionation reaction is plotted as a function of temperature. Table 5 and Figure 5 both suggest that a good way to increase the equilibrium concentration of pentavalent plutonium in an acid solution is to heat the solution. Conversely, some reactions involving pentavalent plutonium as an intermediate may proceed more rapidly at higher temperatures than at lower temperatures because of the suggested increase in the concentration of $\mathrm{Pu}(\mathrm{V})$ at higher temperatures. Unfortunately, the dissociation constant of water increases markedly with increasing temperature, enhancing the probability of hydrolysis of the tetravalent state of plutonium. Hence, it may be of no practical utility to suggest studying Pu(V) in hot solutions. Of course, both Table 5 and Figure 5 are speculations so the above suggestion may not only be impractical but wrong. Curiously, the entropy of the pentavalent plutonium ion is higher than the entropies 
of the other common plutonium ions which also suggests that concentrations of $\mathrm{Pu}(V)$ in solutions of average oxidation number five may be enhanced by raising the temperature of such solutions. 
Acknowledgment: The author wishes to thank C. R. Wendling and $P$. W. Seabaugh for assistance with the calculations. 
Table 1

SOME IDEAL TRIPLE POINTS FOR PLUTONIUM SOLUTIONS

Triple Point

(III, IV , VI)

$[I I I, I V(+$ IVOH $), V I]$

(III, IV, V)

$(\mathrm{III}, \mathrm{V}, \mathrm{VI})$

( IV $, \mathrm{V}, \mathrm{VI})$
Approximate

Acidity (M)

0.3027

$\sim 0.28$

0.1600

0.04473

0.08461
Approximate Oxidation

Number, $\mathrm{N}$

4. 3503

$-4.35$

5.6203

4.6497

3.3797 
Table 2

BEHAVIOR OF PLUTONIUM SPECIES IN NEIGHBORHOOD OF SOME TRIPLE POINTS

PU (4) FIRST REACTIUN CUNSTANT

FOUR STATE EQUILIURIUM CONSTANT =

HYDROLYSIS CONSTANT =

ALPHA FACTOR PU (3)=

ALPHA FACTOR PU $(4)=$

ALPHA FACTOR PU $(6)=$
0.10000000 ol

0.10000000 ol

0.10000000 01
$0.65600000-03$

0.1280000002
PLUTONIUM VALENCE STATE DISTRIBUTION H=

PU (3)

PU (4)

$0.79018230-01$

$0.77772210-01 \quad 0.0$

$0.76515610-01 \quad 0.0$

$0.76515610-01 \quad 0.0$

$0.75246140-01 \quad 0.0$

$0.72675270-01 \quad 0.0$

$0.71374070-01 \quad 0.0$

$0.70059050-01 \quad 0.0$

$0.6873335 \mathrm{D}-01 \quad 0.0$

$\begin{array}{ll}0.6739692 \mathrm{D}-01 & 0.0 \\ 0.6604642 \mathrm{D}-01 & 0.0\end{array}$

$\begin{array}{ll}0.66046420-01 & 0.0 \\ 0.64685060-01 & 0.0\end{array}$

$\begin{array}{ll}0.64685060-01 & 0.0 \\ 0.63309450-01 & 0.0\end{array}$

$\begin{array}{ll}0.63309450-01 & 0.0 \\ 0.61922850-01 & 0.0\end{array}$

$0.60521860-01 \quad 0.0$

$\begin{array}{ll}0.59106380-01 & 0.0 \\ 0.57676330-01 & 0.0\end{array}$

$0.56235050-01 \quad 0.0$

$0.54779090-01 \quad 0.0$

$0.53304910-01 \quad 0.0$

$0.5181938 D-01$

$0.5679986 E$ O

$0.5689985 E$ O

$0.3329999 E \quad 01$ $0.3339998 E$ OI
$0.3349998 E$ OI $0.3359997 E$ OI $0.3369996 E$ OI $0.3379995 \mathrm{E}$ OI $0.3379995 E$ OI $0.3389995 E$ OI $0.3399994 E$ OI $0.3409993 E$
$0.3419992 E$
PU (4)

PU (3)

0.8309686000 0.8267454000 0.8225334000 $0.8183462 \mathrm{D}$ 00 0.8141747000 0.8100267000 0.8058842000 0.8017664000 0.7976519000 0.7935614000 0.7894850000
0.0

0.1600000000

PU $1410 \mathrm{H}$

PU (5)

PU (6)

$0.68586700-01$ $0.62233940-01$ $0.84610000-01$

PU $1410 \mathrm{H}$

0.0
0.0
0.0
0.0
0.0
0.0
0.0
0.0
0.0
0.0
0.0
$0.68221870-01$ $0.6784515 \mathrm{D}-01$ $0.6745551 \mathrm{D}-01$ $0.67053270-01$ $0.6663817 \mathrm{D}-01$ $0.66209850-01$ $0.65766820-01$ $0.65309720-01$ $0.64838120-01$ $0.64350370-01$ $0.63847130-01$ $0.6332663 \mathrm{D}-01$ $0.62789540-01$ $0.6165912 \mathrm{D}-01$ 0.61064330-01 $0.60450220-01$ $0.59814570-01$ $0.59154880-01$ $0.58473270-01$

PU (5)

0.7612699000 0.7652598000 $0.7692608 D 00$ $0.7732798 \mathrm{D} 00$ 0.7732798000 0.7773098000 0.7813498000 0.7853998000 0.7894698000 0.7935498000 0.79763980 DO 0.8017498000 0.8058698000 0.8100098000 0.8141598000 0.81832980 Do 0.8225198000 0.8267298000 0.8309498000 0.8351898000 0.8394598000 0.8437398000

PU (6)

$0.56247710-01$ $0.57690480-01$ $0.59121630-01$ $0.60536560-01$ $0.61938470-01$ $0.63324780-01$ $0.64701590-01$ $0.66062640-01$ $0.67414990-01$ $0.68751930-01$ $0.70076860-01$

.52356000-01 $0.54522000-01$ $0.56708000-01$ $0.58905990-01$ $0.61120000-01$ $0.63345000-01$ $0.65589990-01$ $0.67843990-01$ $0.70118000-01$ $0.7239999 D-01$ $0.74694990-01$ 
Table 2 (continued)

PLUTONIUM VALENCE STATE OISTRIBUTION H=

PU (3)

PU (4)

PU 151

PU (6)

$0.4599998 \mathrm{E} \quad \mathrm{I}$ $0.4609998 \mathrm{E} \quad 01$ $0.4619997 E$ OI $0.4629996 E$ OI $0.4639996 \mathrm{E}$ OL 0.4649995 E 01 $0.4659994 E_{01}$ $0.4669993 \mathrm{E}$ OI $0.4679993 \mathrm{E}$ OI $0.4689992 \mathrm{E}$ OI $0.4699991 E$ OI

\section{$0.2589721 \mathrm{D}-01$}

$0.2579594 \mathrm{D}-01$

$0.2569322 \mathrm{D}-01$

$0.2558899 \mathrm{D}-01$

$0.25483100-01$

$0.25375980-01$

$0.25267200-01$

$0.25156780-01$

$0.2504502 \mathrm{D}-01$

$0.24931900-01$

$0.24817140-01$
PU (4)OH

$0.44730000-01$

0.0
0.0
0.0
0.0
0.0
0.0
0.0
0.0
0.0
0.0
0.0

0.3209669000 0.3217890000 0.3225938000 0.3233816000 0.3241533000 $0.3249058 D 00$ 0.3256418000 0.32636110 0.3270614000 0.3277430000 0.3284073000 0.3263611000
0.3107199000 0.3135399000 0.3163699000 0.3192119000 0.3220699000 0.3249329000 0.3278119000 0.3307069000 0.3307069000
0.3336099000 0.3365219000 0.3394499000

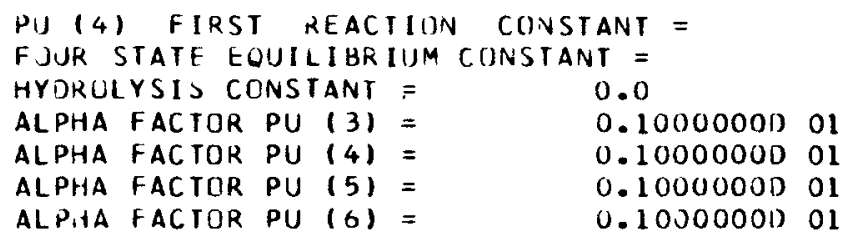

PLUTONIUM VALENCE STATE DISTRIBUTIJN H=

PU (3)

PU (4)

$\begin{array}{ll}0.33947430 & 00 \\ 0.33654580 & 00 \\ 0.33362570 & 00 \\ 0.33072400 & 00 \\ 0.32783210 & 00 \\ 0.32495641) & 00 \\ 0.32208540 & 00 \\ 0.31923040 & 00 \\ 0.31639280 & 00 \\ 0.31356190 & 00 \\ 0.31074330 & 00\end{array}$

0.3283333000 0.3277191000 0.3270357000 0.3263357000 0.3256173000 0.3248923000 0.3248 R2 30 On . 3241278000 0.3233570000 0.1225706000 0.3217657000 0.3209441000
PU 151

0.3027000000

$\begin{array}{ll}0.0 & 0.24820440-01 \\ 0.0 & 0.24935230-01 \\ 0.0 & 0.25048680-01 \\ 0.0 & 0.2516040 D-01 \\ 0.0 & 0.25270720-01 \\ 0.0 & 0.25379380-01 \\ 0.0 & 0.25486820-01 \\ 0.0 & 0.25592600-01 \\ 0.0 & 0.25696690-01 \\ 0.0 & 0.25799450-01 \\ 0.0 & 0.25900680-01\end{array}$

$0.25799450-0$

0.0
PU (6)

0.3073219000 0.3107999000 0.3142899000 0.3177799000 0.3212799000 0.3247819000 0.32829900 0.3282999000 0.3318199000 0.3353399000 0.3388729000 0.3424119000
$0.4399991 \mathrm{E} 01 \quad 0.3107433000$ 
Table 2 (continued)

PIJ (4) rIKST IEACTIIN LLVDTANT =

F JUR STATES LOUILIHKIUA CIIASTANT =

HY MULYSIS CUNSTANT

ALPHA FACTOR PU (3)=

ALPHA FACTIRK PU $(4)=$

ALPHA FACTUR PU $151=$

$A L P H A+A C T O R$ PU $(t)=$
$0.65600000-03$

0.1280000002

$0.30 J 0 \cup \cup(0)-01$

$\left.0.100000 n_{1}\right) 01$

0.10000001101

0.100000000

$0.1000000)$ (1)

RLUTI INI JM VALEINCE STATE OISTRIBUTI JN H=

PU (3)

PU (4)

0.2800000000

p) 14$) 0 \mathrm{H}$

PU $(5)$

PU (6)

0.4249942501 $0.4309991 \mathrm{E} 01$ $0.4319790 \mathrm{H} \cup 1$ $0.4329489 E$ OI $0.4339989 E$ OI $0.4349988 E$ OI 0.4349988 E 1 $\begin{array}{lll}0.4349987 \mathrm{~L} & 01 \\ 0.4369987 \mathrm{~F} & 01\end{array}$ $0.4379986 t \quad 01$ $0.4389985 \mathrm{~F} \quad 01$ $0.4399984 E$ UI $0.4409984 \mathrm{E}$ OI
0.37715700 o0 $0.32649450 \quad 00$ $0.32581<31) 00$ 0.3251144000 0.3243977000 0.3236627000 . 3229113000 0.3221406000 0.3213556000 0.3205515000 0.31973170 0.3188943100
$0.31650410-01$ $0.31596260-0$ $0.31530270-01$

$0.31462690-01$

$0.31393330-01$

$0.31322200-01$

$0.3124948 \mathrm{D}-0$

$0.31174900-01$

$0.31098930-01$

$0.3102112 \mathrm{D}-01$

$0 . \$ 094178 \mathrm{D}-0$

$0.30860740-01$
$0.27456660-01$ $0.27583870-01$ $0.27709570-01$ $0.27833340-01$ $0.2795556 \mathrm{D}-01$ $0.28076220-01$ $0.2819504 \mathrm{D}-01$ $0.28312510-01$ $0.2842788 \mathrm{D}-01$ $0.2854188 \mathrm{D}-01$ $0.28654070-0$ $0.28764680-01$
0. 3059709000 0.3094399000 0.3129199000 0.3163999000 $0.3198899 \mathrm{D} 00$ 0.3233899000 $0.3233899 D$
0.3268919000 0.3268919000
0.3304099000 0.3339219000 0.3374499000 0.3409799000 0.3445199000 
15. G. L. Silver, Nature of the Steady State of Plutonium-238 in Dilute Nitric and Hydrochloric Acids, MLM-1709 (1970).

16. R. Belcher and C. Wilson, New Methods in Analytical Chemistry, Chapman and Hall Ltd., London, 1964, p. 29.

17. H. Lahr and W. Knoch, Radiochimica Acta, 13, 1-5 (1970).

18. J. A. Perez-Bustamante, Fundamental Aspects of Plutonium Chemistry II. Oxidation States of the Element, USAEC Report MLM-1747(TR), July 10, 1970.

19. J. A. Perez-Bustamante, Radiochimica Acta, 4, 67 (1965). 
APPENDIX I 
In manufacturing processes involving plutonium, it is sometimes desirable to ascertain the distribution of plutonium valence states in dilute aqueous acids of this element. This may be done, for example, by spectrophotometry.15 This method is somewhat lengthy, however, since it requires the preparation of reliable spectrophotometric standard solutions, clean cells, measurement of "base line" absorption, and adjustment of measurement conditions so that the light absorption by the plutonium solution is neither too intense nor too weak. Moreover, a spectrophotometric method applicable to nitric acid may not be applicable to sulfuric acid. It would, therefore, seem desirable to have available another method of making valence state determinations. Two suggested methods of making plutonium valence state determinations are listed below.

1. By application of either Equation (33) or Equation (34), the ratio $\mathrm{Pu}(\mathrm{VI}) / \mathrm{Pu}(\mathrm{V})$ may be ascertained. This ratio is denoted " $\mathrm{M}$ ". In these equations, $E(S)$ is the measured solution potential (vs. NHE) and is a positive number which may be rapidly and easily obtained by inserting a platinum-reference electrode pair into the plutonium solution of interest.

$$
\begin{aligned}
& \frac{E(S)-E(6,5)}{0.05916}=\log M(5,6) . \\
& \frac{E(S)-E(4,3)+0.05916 \log K_{2}}{0.05916}=\log M(3,4) .
\end{aligned}
$$

When the value of " $\mathrm{M}$ " has been ascertained, it may be substituted into Equation 35 to determine the fraction of $\mathrm{PuO}_{2}^{+}$consistent with the potential. Application of Equations (36), (37), (38), and (39) provides a measure of the fractions of other plutonium species.

$$
\begin{aligned}
& \mathrm{Y}=\left[\frac{(\mathrm{AW})\left(\mathrm{K}_{2}^{2}\right)\left(\mathrm{H}^{4}\right)}{\mathrm{K}_{1} \mathrm{M}^{\beta}}+\frac{(\mathrm{AX}+\mathrm{KH} / \mathrm{H})\left(\mathrm{H}^{4}\right)\left(\mathrm{K}_{2}\right)}{\mathrm{K}_{1} \mathrm{M}}+(\mathrm{AY})+\mathrm{M}(\mathrm{AZ})\right]^{-1} \cdot \\
& \mathrm{Pu}(\mathrm{III})=\frac{\left(\mathrm{K}_{2}^{2}\right)(\mathrm{Y})\left(\mathrm{H}^{4}\right)(\mathrm{AW})}{\mathrm{K}_{1} \mathrm{M}^{\beta}} \cdot \\
& \mathrm{Pu}(I V)=\frac{\left(\mathrm{K}_{2}\right)(\mathrm{Y})\left(\mathrm{H}^{4}\right)(\mathrm{AX}+\mathrm{KH} / \mathrm{H})}{\mathrm{K}_{1} \mathrm{M}} . \\
& \mathrm{Pu}(\mathrm{IV}) \mathrm{OH}=\frac{\left(\mathrm{K}_{2}\right)(\mathrm{Y})\left(\mathrm{H}^{4}\right)(\mathrm{KH} / \mathrm{H})}{\mathrm{K}_{1} \mathrm{M}} . \\
& \mathrm{Pu}(\mathrm{VI})=\operatorname{MY}(\mathrm{AZ}) .
\end{aligned}
$$

The principal advantage of this method is speed: the determination of solution acidity and emf (vs. NHE) is rapidly accomplished. The disadvantages of this method are many. The method requires accurate knowledge of the solution acidity. In recent years, various methods for making this acidity determination have been proposed. Doubtless all of these methods 
are satisfactory for making solution acidity estimations. A survey of these methods suggests that a reliable method for obtaining an accurate value of the acidity of plutonium solutions may not yet be available. Since the acidity value appears in Equation (35) raised to the fourth power, an estimation of this variable will not ordinarily be satisfactory. Hence, the practical application of this method may be limited by the lack of suitable methods for determining accurately the acidity of plutonium solutions. In nitrate solutions, this problem may be further complicated by the incomplete dissociation of the $\mathrm{HNO}_{3}$ molecule.

This method also has another practical drawback: the requirement of $E(S)$. The solution potential, like the solution acidity, may be estimated quickly. Unfortunately, an estimated value of $E(S)$ may not be satisfactory. An error of $60 \mathrm{mV}$ in $\mathrm{E}(\mathrm{S})$ will change the value of $\mathrm{M}$, the $\mathrm{Pu}(\mathrm{VI}) /$ $\mathrm{Pu}(\mathrm{V})$ ratio, by a factor of 10. Reliable electrodes and a reliable standard potential buffer are required for the practical application of this technique. ${ }^{16}$ The method suffers still another shortcoming: alpha factors for plutonium species can only be estimated since there is generally a lack of reliable formation constants for plutonium ions with various anions such as nitrate. ${ }^{17}$

On the following pages is a computer program by Carl Wendling for determining plutonium valence state distributions given the standard potentials for the $\mathrm{Pu}^{4+}, \mathrm{Pu}^{3+}$ and $\mathrm{PuO}_{2}{ }^{2+}, \mathrm{PuO}_{2}{ }^{+}$couples, the measured solution acidity $(\mathrm{H})$, the positive solution potential (vs. NHE) [denoted $\mathrm{E}(\mathrm{S})$ ], and the alpha factors for all plutonium oxidation states. For each combination of $\mathrm{H}$ and $\mathrm{E}(\mathrm{S})$ the program computes two valence state distributions: one based upon information relating to the $\mathrm{Pu}^{4+}, \mathrm{Pu}^{3+}$ couple, and one based upon information relating to the $\mathrm{PuO}_{z}{ }^{2+}, \mathrm{PuO}_{z}{ }^{+}$couple. Ideally, these distributions should agree.

A practical application of this method is suggested in Reference 15. In this reference, the potentials of nitric acid solutions of ${ }^{238} \mathrm{Pu}$ were measured experimenta11y, and the distribution of plutonium valence states was also determined experimentally by a spectrophotometric technique. For the potential determinations, a buffer solution consisting of ferric chloride and ferrous chloride in dilute hydrochloric acid was assumed to have a potential of $700 \mathrm{mV}$. (Since the potential of this buffer is reported to two significant figures only, an error of $10 \mathrm{mV}$ in the true value of the potential of this buffer is not unreasonable). The potential of an $8.74 \mathrm{mg} / \mathrm{ml}$ solution of $238 \mathrm{Pu}$ in $0.34 \mathrm{M}$ nitric acid was ascertained to be about $0.95 \mathrm{~V}$. Assuming $\mathrm{H}$ to be $0.3 \overline{4} \mathrm{M}$, alpha factors for $\mathrm{Pu}(\mathrm{III}), \mathrm{Pu}(\mathrm{IV}), \mathrm{Pu}(\mathrm{V})$, and $\mathrm{Pu}(\mathrm{IV})$ to be $5.6,9.0,1.0$, and 1.1 , respectively, and measured solution potential to be $0.95 \mathrm{~V}$ leads to the following distribution of plutonium valence states: $\mathrm{Pu}($ III $)=67.9 \%, \mathrm{Pu}(\mathrm{IV})=$ $31.8 \%$, and $\mathrm{Pu}(\mathrm{VI})=0.2 \%$ compared to the observed distribution of valence states: $\mathrm{Pu}(\mathrm{III})=57 \%, \mathrm{Pu}(\mathrm{IV})=43 \%$, and $\mathrm{Pu}(\mathrm{VI})=0.5 \%$. A comparison of the observed values and the computer predicted values shows considerable difference (although these errors might be tolerable for some applications in manufacturing processes). The discrepancy in observed and predicted 
values might arise in several ways, one of them being an erroneous solution potential. Increasing the observed solution potential to $0.96 \mathrm{~V}$ leads to the distribution $\mathrm{Pu}($ III $)=58.7 \%, \mathrm{Pu}(\mathrm{IV})=40.6 \%$, and $\mathrm{Pu}(\mathrm{VI})=$ $0.5 \%$, which is much closer to the observed valence state distribution. It seems reasonable to believe, therefore, that the absolute values of the potentials reported in Reference 15 may be in error by about $10 \mathrm{mV}$. The most likely cause of this error is the standard buffer. It is also possible, however, that the measured acidity is in error, or that the assumed alpha factors for plutonium in $0.34 \mathrm{M}$ nitric acid are incorrect. (Although the absolute values of the potentials reported in Reference 15 may be in error by about $10 \mathrm{mV}$, the potential-acidity behavior would not be affected by this proposed error.)

2. Determination of plutonium valence distributions by a purely spectrophotometric method involves absorbancy measurements at more than one wavelength. This is time consuming, tedious, and subject to error in absorbancy at each wavelength. The species $\mathrm{PuO}_{3}{ }^{3+}$ has a sharp and pronounced absorption near $831 \mathrm{~nm}$. A correlation of the magnitude of this peak with the fraction of plutonium present as $\mathrm{PuO}_{2}{ }^{2+}$ (amount of $\mathrm{PuO}_{2}{ }^{2+}$ divided by total plutonium) is much easier.15 Unfortunately, this correlation is nonlinear, since light absorption by $\mathrm{PuO}_{2}{ }^{2+}$ near $831 \mathrm{~nm}$ does not follow Beer's Law. ${ }^{15}$ However, the absorbancy of this peak may be relatively insensitive to "base line" absorbancy errors as well as absorbancy due to other light absorbing species as illustrated in Figure 6 . The second computer program by Carl Wendling below will provide a plutonium valence state distribution based upon solution acidity (H) and fraction of $\mathrm{PuO}_{2}{ }^{2+}(\mathrm{Z})$. In this connection, it is to be remembered that what is measured spectrophotometrically as in Figure 6 is not $Z$, but $\mathrm{Z}(\mathrm{AZ})$. The second program solves Equations (40)-(45). In instances where the absorbancy of Pu(VI) near $831 \mathrm{~nm}$ is not useful, another absorption of $\mathrm{Pu}(\mathrm{VI})$ in the near infrared region of the spectrum might be useful. The concept of using a particular fraction of plutonium in order to determine the entire valence state distribution may be generalized to any plutonium species.

$$
\begin{aligned}
& 0=\frac{(\mathrm{AW})\left(\mathrm{K}_{2}\right)^{2}\left(\mathrm{Y}^{3}\right)\left(\mathrm{H}^{4}\right)}{\left(\mathrm{K}_{1}\right)\left(\mathrm{Z}^{2}\right)}+\frac{(\mathrm{AX}+\mathrm{KH} / \mathrm{H})\left(\mathrm{Y}^{2}\right)\left(\mathrm{H}^{4}\right)\left(\mathrm{K}_{\mathrm{E}}\right)}{\mathrm{K}_{\mathrm{I}} \mathrm{Z}}+\mathrm{Y}(\mathrm{AY})+\mathrm{Z}(\mathrm{AZ})-1 \\
& \mathrm{Pu}(\mathrm{IV})=\frac{\mathrm{K}_{2} \mathrm{Y}^{2}\left(\mathrm{H}^{4}\right)(\mathrm{AX}+\mathrm{KH} / \mathrm{H})}{\mathrm{K}_{1} \mathrm{Z}} \\
& \operatorname{Pu}(I I I)=\frac{\left(K_{2}\right)^{2}\left(Y^{3}\right)\left(H^{4}\right)(A W)}{K_{1} Z^{2}} \\
& \mathrm{Pu}(\mathrm{VI})=\mathrm{Z}(\mathrm{AZ}) \\
& \mathrm{Pu}(\mathrm{V})=\mathrm{Y}(\mathrm{AY}) \\
& \mathrm{Pu}(\mathrm{IV}) \mathrm{OH}=\frac{\mathrm{K}_{2} \mathrm{Y}^{2}\left(\mathrm{H}^{4}\right)(\mathrm{KH} / \mathrm{H})}{\mathrm{K}_{1} \mathrm{Z}}
\end{aligned}
$$


As an example of an application of this program, the proportions of tetravalent and trivalent ${ }^{3}$ з $\mathrm{Pu}$ in $0.34 \mathrm{M}$ nitric acid ${ }^{15}$ may be estimated given that the proportion of hexavalent plutonium is 0.005 or 0.010 . The alpha factor ${ }^{7}$ for $\mathrm{Pu}$ (III) may be taken to be 5.6 , for $\mathrm{Pu}$ (IV) to be 9.0 , for $\mathrm{Pu}(\mathrm{V})$ to be 1.0, and for $\mathrm{Pu}(\mathrm{VI})$ to be 1.1. Hence, the proportion of ionic hexavalent plutonium in these two cases is 0.004545 and 0.009091 , respectively. The program predicts that the proportions of $\mathrm{Pu}$ (III) and $\mathrm{Pu}(\mathrm{IV})$ in the first case should be, respectively, $59.8 \%$ and $39.6 \%$ compared to observed fractions of $57 \%$ and $43 \%$. In the second case, the predicted proportions of $\mathrm{Pu}$ (III) and $\mathrm{Pu}(\mathrm{IV})$ are, respectively, $52.9 \%$ and $45.9 \%$ compared to respective observed values of $51 \%$ and $48 \%$. When the above alpha factors for $\mathrm{Pu}$ (III) and $\mathrm{Pu}$ (IV) are changed to 11.1 and 18.1 , respectively, the valence state distribution in $0.71 \mathrm{M}$ acid is $17.5 \% \mathrm{Pu}(\mathrm{III})$ and $81.1 \% \mathrm{Pu}(\mathrm{IV})$, compared to observed values of $20 \%$ $\mathrm{Pu}(\mathrm{III})$ and $79 \% \mathrm{Pu}(\mathrm{IV})$. For this estimation, ${ }^{15}$ ionic $\mathrm{Pu}(\mathrm{VI})$ was taken as $1.1182 \%$. 
PURPUSE:

TU CALCULATE THE OISTRIBUTION JF PLUTJNIUM VALENCE STATES

60

FROU 70

FRPU 80

INPUT VARIABLE FORMAT:

FRPU 90

FKPU 100

FIRST CARD:

1) COLUMN 1 CARD CODE $=1$ ' '

2) COLUYN 11-20 PU(4) FIRST REACTION CUNSTANT-OKI

FRPU 110

FRPU 120

3) COLUMN 21-30 FOUR STATES EQUILIBRIUM CONSTANT--K2

FRPU 130

FRPU 140

FRPU 150

FRPU 160

FRPU 170

SECOND CARD:

1) COLUMN 1 CARD CODE $=.2$ '

2) COLUMIV 11-20 ALPHA FACTOR PU(3)--AW

3) COLUMN 31-40 ALPHA FACTOR PU(4)--AX

4) COLUMN 41-50 ALPHA FACTOR PU(5)--AY

5) COLUMIN 51-60 ALPHA FACTOR PU(6)--AZ

THIRD CARD:
1) COLUMN 1 CARD CODE $=3$ '
2) COLUMN 11-20 FQUILIBRIUM ACIDITY(M)--H
3) COLUMN 21-30 FRACTION PU(6)--Z

NOTE: ANY COMBINATION OR NUMBER OF INPUT CARDS MAY BE RAN.

EXAMPLE: $\quad 1,2,3,3,2,3$

OR

$1,2,3,3,1,2,3,2,3$

SUBRUUTINES REQUIRED:

DRINI-- NEWTON-S INIERATION METHOD-DOUBLE PRESICION (SYSTEM/360 SSP)

$\triangle W>0.0$ FRPU

$\triangle X>0.0$ FRPU 20

$A Y>0.0$ FRPU 210

$A Z>0.0$ FRPU 220

FRPU 230

FR.PU 240

FRPU 250

FRPU 260

FRPU 270

FRPU 280

FRPU 290

FRPU 300

FRPU 310

FRPU 320

FRPU 330

FRPU 340

FRPU 350

FRPU 360

FRPU 370

FRPU 380

FRPU 390

FRPU 400 
r

EXTERNAL FUNC

CUMMON $K 2, K 1, A W, A X, A Y, A Z, K H, H H, Z, H$

0004

0005

0006

0007

0008

0009

0010

0011

0012

0013

0014

0015

0016

0017

0018

0019

0020

0021

0022

0023

0024

0025

0026

0027

0028

0029

0030

0031

DDUBLE PRECISION K2,KI, AW,AX,AY,AZ,KH,HH,Z,H,XST,F,DER,Y, N, X,PU3

1 PU4, PU4UH,PU5,PUB $, A, B, C, D$

$E=1.0 E-06$

$X S T=.01 E 0$

$N N=500$

8 READ $(1,1, E N D=100) N, A, B, C, D$.

IF $(N . E Q .2) \quad G 0$ TD 9

IF $(N . E Q .3)$ GU TU 10

$K 1=A$

$K 2=B$

$\mathrm{KH}=\mathrm{C}$

WRITE $(3,3) \mathrm{Kl}, \mathrm{K} 2, \mathrm{KH}$

GO TIJ 8

$9 \quad A H=A$

$A X=B$

$A Y=C$

$A Z=D$

WR I TE $(3,2)$ AW, AX,AY,AZ

GO TO 8

$10 \mathrm{H}=\mathrm{A}$

$Z=B$

WR ITE $(3,7) 2$

WR ITE $(3,6) \mathrm{H}$

$H H=H * H * H * H$

CALL DRTNI (Y,F, DER, FUNC, XST,E,NN, IER)

IF (IER.EQ.1) GO TO 98

IF (IER.EQ.2) GO TO 99

GO TO 97

98 WRITE $(3,12)$

99 WRITE $(3,5)$

FRPU 412

FRPU 420

FRPU 430

FRPU 440

FRPU 450

FRPU 470

FKPUI 480

FRPU 490

FRPU 500

FRPU 510

FRPUJ 520

FRPU 532

FRPU 540

FRPU 550

FRPU 56 ?

FRPU 570

FRPU 580

FRPU 590

FRPU 600

FRPU 610

FRPU 620

FRPU 630

FRPU 640

FRPU 650

FRPU 660

FRPU 670

FRPU 680

FRPU 690

FRPU 700

FRPU 710

FRPU 720

FRPU 730

FRPU 740

FRPU 750

FRPU 160

FRPU 770

FRPU 780

FRPU 790 
2 FORMAT (////20X,'ALPHA FACTUR PU (3) =, FRPU 920 3E20.7/20X,'ALPHA FACTOR PU $141=$, t20.7/20X,'ALPHA FACTOR PU (5)FRPU 930 $4=1, E 20.7 / 20 X$, ALPHA FACTOR PU $(6)=\cdot, E 20.7) \quad$ FRPU 940

3 FURMATIIHL, 9X, 'PU (4) FIRST REACIION CONSTANT $=1, F 20.7 /$ FRPU 950 1LOX,'FOUR STATES EQUILIBRIUM CONSTANT $=1,1 X_{1} F 20.7 / 10 X, \quad$ FRPU 960 2 'HYOROLYSIS CONSTANT $=$ ',E20.7)

0045

0046

4 FORMAT $(10 X, 5 I E 20.7))$

6 FORMATI $30 x, \cdot$ PLUTUNIUM VALENCE STATE DISTRIBUTIUN H= , E 20.711

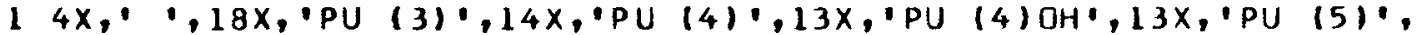
$212 x, \cdot P U(6) \cdot 11$

0047

12 FURMAT (' ERROR = 1')

100 CONTINUE END

0008

0009

0010

SURRUUT IINE FUNC(Y,F, DER)

FRPU1060

CUMMON K2,K1,AW, AX, AY, AZ, KH,HH, Z,H

DOUBLE PRECISIUN KZ,K1,H,Z,F,DER, Y, AW, AX, AY, AZ, KH, HH

If $(Y) 1,2,2$

$1 Y=O A B S(Y)$

2 CONIINUE

$F=(A W * K Z * K 2 * Y * Y * Y * H H) /(K I * Z * Z)+((A X+K H / H) * Y * Y * H H * K 2) /(K 1 * Z)+Y *$

FRPUF 10

FRPUF 20

FRPUF 3)

FRPUF 40

FRPUF 50

FRPUF 63

$1 A Y+Z * A Z-1$

FRPUF 7U

$D E R=13 . A N * K 2 * K 2 * Y * Y * H H) /(K 1 * Z * Z)+(2 . *(A X+K H / H) * Y * H H * K 2) /(K L * Z)$

$1+A Y$

FRPUF 80

END

FRPUF 100

FPPUF 113

FRPUF 123 


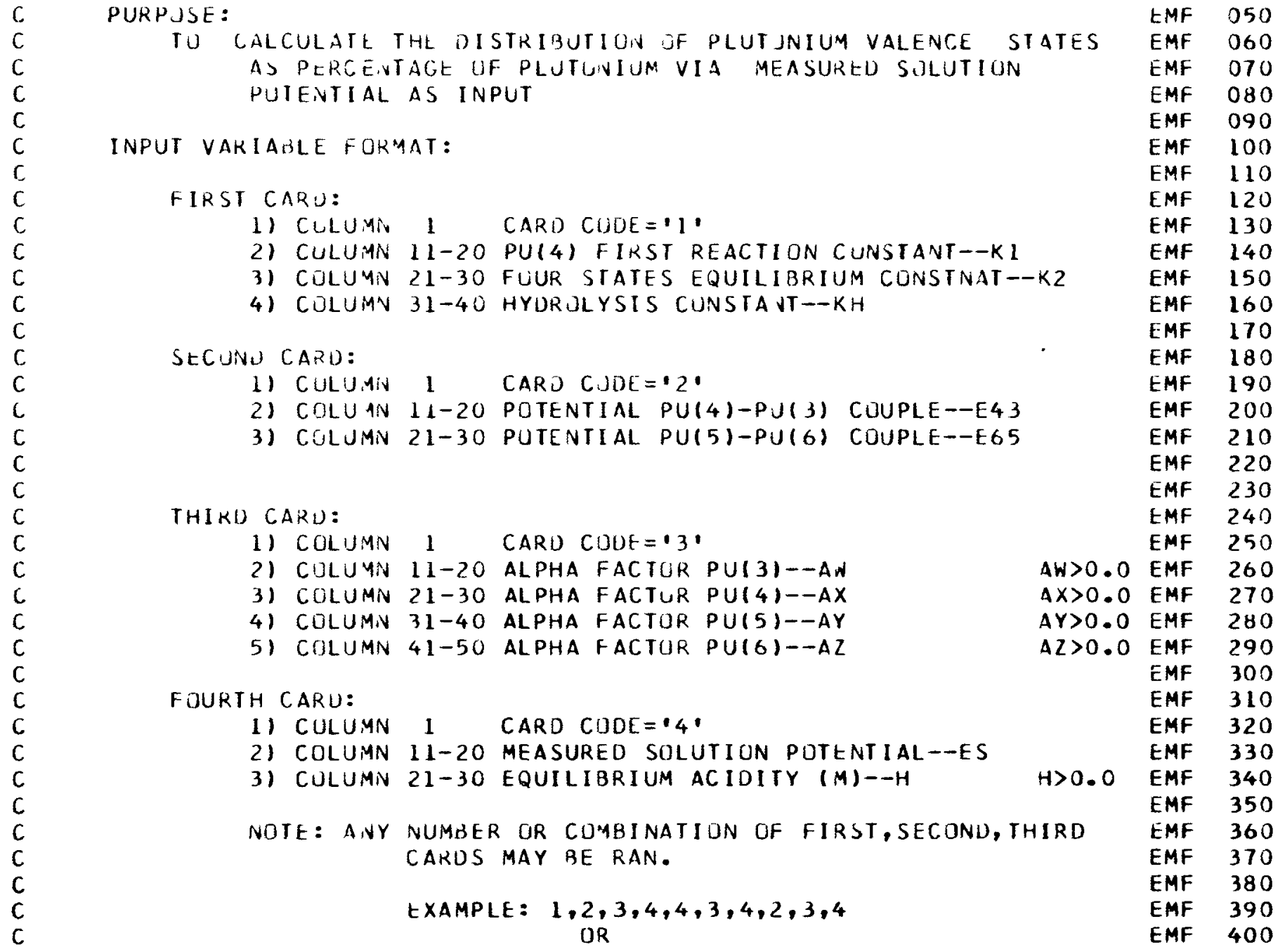


DUUBLE PRECISION A,H,C,O,KI,K2,KH,E43,E65, AW, AX,AY, AZ,ES,H, HH,

$11 E S=A$

$H=B$

WRITE $(3,5)$ ES

WR ITE $(3,6) \quad H$

$H H=H * H * H * H$

$A R G 1=(E S-E 65) / 0.05916$

$M=10.00 * * A R G 1$ 


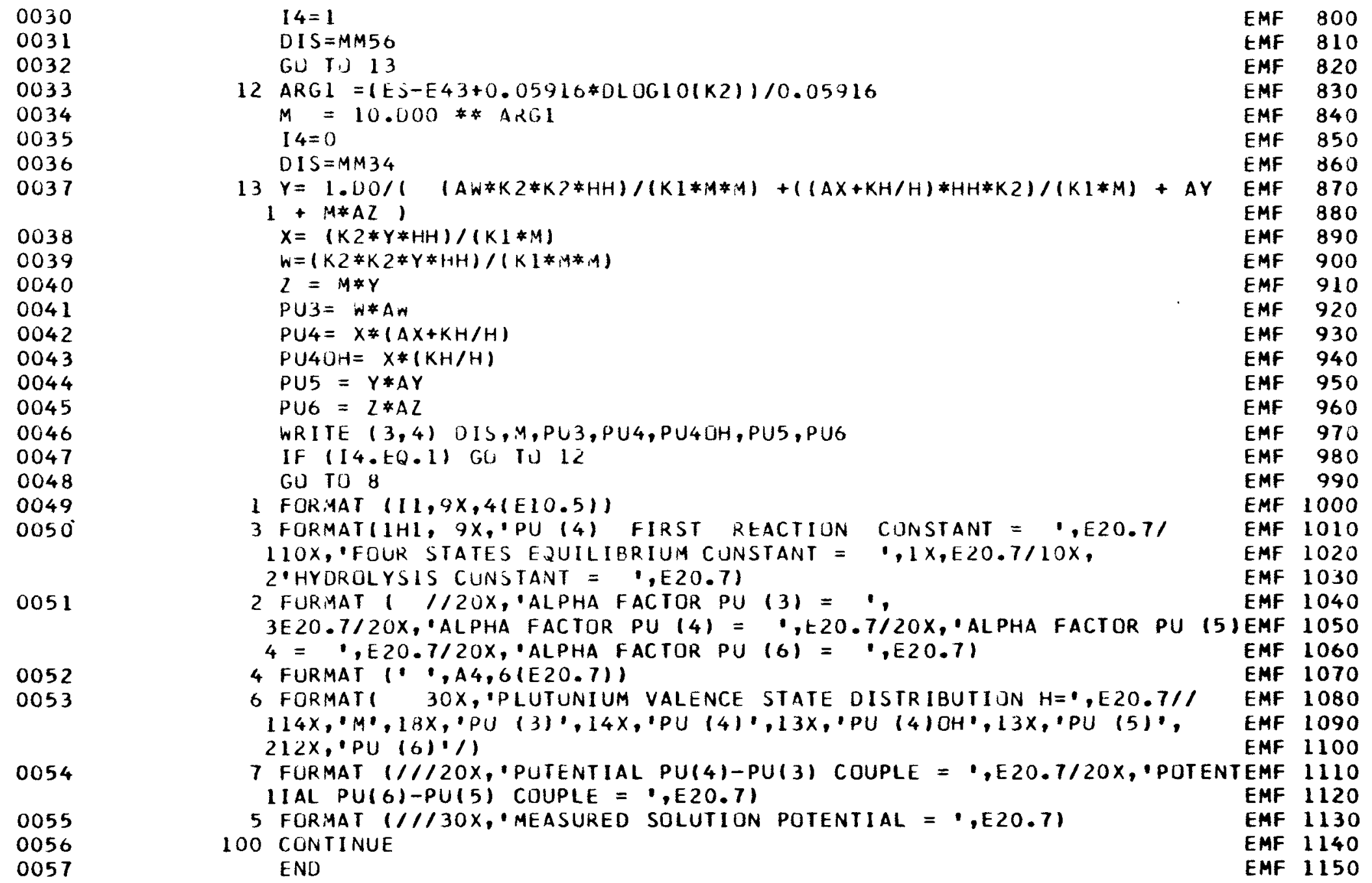


This page

intentionally

left blank 


\section{APPENDIX II}


When considering plutonium reactions, it is occasionally desirable to have available for immediate reference some thermodynamic quantities even though the values of some of these quantities may be known only approximately. In the table below are presented some thermodynamic quantities for plutonium. These values for the most part are only approximate and were derived with the aid of the potential scheme:

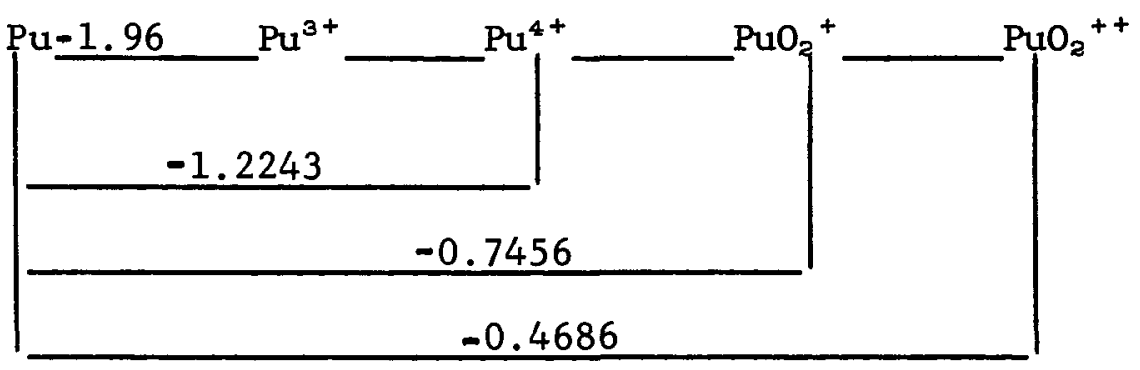

and the reaction ${ }^{6}$

$$
\mathrm{Pu}^{3+}+\mathrm{H}^{+}=\mathrm{Pu}^{4+}+\frac{1}{2} \mathrm{H}_{2} \quad \Delta \mathrm{S}=30.2 \frac{\mathrm{cal}}{\mathrm{deg}-\mathrm{mole}}
$$

SOME APPROXIMATE

\begin{tabular}{|c|c|c|c|}
\hline Species & $\begin{array}{c}F \\
\text { (kcal/mole) }\end{array}$ & $\begin{array}{c}\mathrm{H} \\
(\mathrm{kcal} / \mathrm{mole})\end{array}$ & $\begin{array}{c}\mathrm{S} \\
(\mathrm{cal} / \mathrm{deg} \text {-mole })\end{array}$ \\
\hline $\mathrm{Pu}^{3+}$ & $-135.8^{b}$ & $-138.9^{b}$ & $-44.6^{b}$ \\
\hline $\mathrm{Pu}^{4+}$ & -112.94 & -124.94 & -90.4 \\
\hline $\mathrm{PuO}_{2}{ }^{+}$ & -199.35 & -214.78 & $-06.0^{a}$ \\
\hline $\mathrm{PuO}_{2}{ }^{++}$ & -178.22 & -192.93 & $-19.2^{\mathrm{a}}$ \\
\hline $\mathrm{Pu}$ & 0 & 0 & $12.3^{b}$ \\
\hline
\end{tabular}

THERMODYNAMIC QUANTITIES FOR PLUTONIUM

\footnotetext{
a

J. R. Brand and J. W. Cobble, Inorg. Chem., 9, 912-17 (1970)

b

Reference 5 .
} 
APPENDIX III 
SOME OXISTATIC RATIOS FOR PLUTONIUM ${ }^{a}$

$$
\mathrm{N}=4.5
$$

$H(M)$
300
100
30
10
3
1
0.3
0.1
0.03
0.01
0.003
0.001

$$
\underline{\mathrm{Pu}}(\mathrm{VI}) / \mathrm{Pu}(\mathrm{V})=\mathrm{M}
$$

$7.153 \times 10^{6}$

$7.948 \times 10^{5}$

$7.155 \times 10^{4}$

$7.967 \times 10^{3}$

$7.342 \times 10^{2}$

$9.451 \times 10$

$1.388 \times 10$

2.887

$4.970 \times 10^{-1}$

$7.805 \times 10^{-2}$

$7.771 \times 10^{-3}$

$8.651 \times 10^{-4}$

a - Neglecting Hydrolysis

$$
\mathrm{N}=3.5
$$

$\mathrm{H}(\mathrm{M})$
300
100
30
10
3
1
0.3
0.1
0.03
0.01
0.003
0.001

\section{$\underline{\mathrm{Pu}}(\mathrm{VI}) / \mathrm{Pu}(\mathrm{V})=\mathrm{M}$}

13.20

13.20

13.20

13.20

13.19

12.64

5.884

1.467

$2.204 \times 10^{-1}$

$2.819 \times 10^{-2}$

$2.593 \times 10^{-3}$

$2.887 \times 10^{-4}$ 
PENTAVALENT PLUTONIUM $(\mathrm{N}=5.0)$

\begin{tabular}{l}
$\mathrm{H}(\underline{\mathrm{M}})$ \\
\hline 100 \\
30 \\
10 \\
3 \\
1 \\
0.8 \\
0.6 \\
0.4 \\
0.2 \\
0.1 \\
0.03 \\
0.01 \\
0.003 \\
0.001
\end{tabular}

\section{$\underline{\mathrm{Pu}(\mathrm{VI}) / \mathrm{Pu}(\mathrm{V})=\mathrm{M}}$}

$1.376 \times 10^{6}$

$1.238 \times 10^{5}$

$1.377 \times 10^{4}$

1. $251 \times 10^{3}$

149.26

99.09

59.51

30.15

10.37

3.855

0.7467

0.1713

$3.435 \times 10^{-2}$

$7.937 \times 10^{-3}$

\section{TETRAVALENT PLUTONIUM $(\mathrm{N}=4.0)$}

\begin{tabular}{c}
$\mathrm{H}(\underline{\mathrm{M}})$ \\
\hline 100 \\
30 \\
10 \\
3 \\
1 \\
0.8 \\
0.6 \\
0.4 \\
0.2 \\
0.1 \\
0.03 \\
0.01 \\
0.003 \\
0.001
\end{tabular}

$\underline{\mathrm{Pu}}(\mathrm{VI}) / \mathrm{Pu}(\mathrm{V})=\mathrm{M}$

$2.321 \times 10^{4}$

$4.661 \times 10^{3}$

$1.077 \times 10^{3}$

$2.162 \times 10^{2}$

49.84

36.97

25.14

14.57

5.687

2.166

0.3460

$4.778 \times 10^{-2}$

$4.481 \times 10^{-3}$

$4.998 \times 10^{-4}$ 


$$
N=5.5
$$

\begin{tabular}{l}
$H(\underline{M})$ \\
\hline 300 \\
100 \\
30 \\
10 \\
3 \\
1 \\
0.3 \\
0.1 \\
0.03 \\
0.01 \\
0.003 \\
0.001
\end{tabular}

$\underline{\mathrm{Pu}(\mathrm{VI}) / \mathrm{Pu}(\mathrm{V})=\mathrm{M}}$

$2.146 \times 10^{7}$

$2.384 \times 10^{6}$

$2.146 \times 10^{5}$

$2.385 \times 10^{4}$

$2.157 \times 10^{3}$

$2.492 \times 10^{2}$

$2.897 \times 10$

5.758

1.488

1.013

1.000

1.000 
APPENDIX IV 
The predominance region diagram (Figure 2) is incomplete in that it omits the hydrous oxides of plutonium. The diagram and the method used to prepare the diagram are nevertheless of value since they demonstrate the general chemistry of plutonium valence states without regard to the precipitation of solid phases. The understanding of this general behavior (corrected perhaps for the first and successive hydrolysis reactions of the tetravalent plutonium ion) solves the general plutonium equilibrium problem, and is of academic interest. It may be of practical interest in studying the behavior of plutonium accidentally released to nature, where the concentration would hopefully be insufficient to allow the precipitation of thehydrous oxides as pure phases. Hence, the diagram and the method used to prepare the diagram may be useful in studies where the behavior of traces of plutonium are of interest, but not so useful to the manufacturer who is interested in the behavior of plutonium on a large scale, and, therefore, needs a "practical" predominance region diagram even though the chemistry of plutonium is not yet well enough advanced to present a "practical" diagram applicable to all circumstances of radioactivity, acidity, temperature, concentration, and prior history of the element. A practical predominance region diagram should include the hydrous oxides. In this case, pentavalent plutonium is unstable both in high acid and in media where at least one hydrous oxide forms.

$$
\begin{aligned}
& 2 \mathrm{PuO}_{2}^{+}+2 \mathrm{H}_{3} \mathrm{O}=\mathrm{PuO}_{2}^{++}+\mathrm{Pu}(\mathrm{OH})_{4} \Delta \mathrm{F} \sim-4.3 \mathrm{kcals} / \mathrm{mole} \\
& 2 \mathrm{PuO}_{2}^{+}+2 \mathrm{OH}^{-}+2 \mathrm{H}_{2} \mathrm{O}=\mathrm{Pu}(\mathrm{OH})_{4}+\mathrm{PuO}_{2}(\mathrm{OH})_{3} \Delta \mathrm{F} \sim-35.6 \mathrm{kcals} / \mathrm{mole} \\
& 2 \mathrm{PuO}_{2} \mathrm{OH}+2 \mathrm{H}_{2} \mathrm{O}=\mathrm{Pu}(\mathrm{OH})_{4}+\mathrm{PuO}_{2}(\mathrm{OH})_{2} \Delta \mathrm{F} \sim-10.1 \mathrm{kcals} / \mathrm{mole}
\end{aligned}
$$

Some reactions which must be considered in the preparation of a practical plutonium predominance region diagram are the following 10 expressions. The region boundaries in Figure 7 are described by these 10 expressions and are numbered accordingly. Potentials are taken from Cleveland. The diagram is drawn for soluble plutonium species of $0.01 \mathrm{M}$ concentration. The solubility product of $\mathrm{Pu}(\mathrm{OH})_{4}$ was taken as $10^{-55}$, of $\mathrm{Pu}(\mathrm{OH})_{3}$ as $10^{-30}$, and of $\mathrm{PuO}_{2}(\mathrm{OH})_{2}$ as $10^{-23}$. Solubility products for plutonium species are poorly defined, as Perez-Bustamante has pointed out. ${ }^{18}$

1. $\left(\mathrm{Pu}^{3+}\right)\left(\mathrm{OH}^{-}\right)^{3}=10^{-30}$

2. $\mathrm{Pu}(\mathrm{OH})_{4}+\varepsilon=\mathrm{Pu}(\mathrm{OH})_{3}+\mathrm{OH}^{-} ; \mathrm{E}=0.2605-0.05916 \mathrm{pH}$

3. $\mathrm{Pu}(\mathrm{OH})_{4}+\varepsilon=\mathrm{Pu}^{3+}+4 \mathrm{OH}^{-} ; \mathrm{E}=1.1593-4(0.05916) \mathrm{pH}$

4. $\mathrm{PuO}_{2}(\mathrm{OH})_{2}+2 \mathrm{H}_{2} \mathrm{O}+2 \varepsilon=\mathrm{Pu}(\mathrm{OH})_{4}+20 \mathrm{H}^{-} ; \mathrm{E}=1.1617-0.05916 \mathrm{pH}$

5. $\mathrm{PuO}_{2}^{++}+2 \varepsilon+\mathrm{H}_{2} \mathrm{O}=\mathrm{Pu}(\mathrm{OH})^{4} ; \mathrm{E}=0.9546$

6. $\mathrm{PuO}_{2}^{++}+4 \mathrm{H}^{+}+2 \varepsilon=\mathrm{Pu}^{4+}+2 \mathrm{H}_{2} \mathrm{O} ; \mathrm{E}=1.0433-0.1183 \mathrm{pH}$ 


$$
\begin{aligned}
& \text { 7. } \mathrm{Pu}^{4+}=\mathrm{Pu}^{3+}+\epsilon ; \mathrm{E}=0.9819 \\
& \text { 8. } \mathrm{PuO}_{3}^{++}+4 \mathrm{H}^{+}+3 \epsilon=\mathrm{Pu}^{3+}+2 \mathrm{H}_{2} \mathrm{O} ; \mathrm{E}=1.0228-0.0789 \mathrm{pH} \text {; hexavalent } \\
& \text { plutonium is reduced, but predominately } \mathrm{Pu}^{3+} \text { results since both in- } \\
& \text { termediate oxidation states are subject to disproportionation in } \\
& \text { this acidity range. } \\
& \text { 9. }\left(\mathrm{PuO}_{2}^{++}\right)(\mathrm{OH})^{2}=10^{-33} \\
& \text { 10. } \mathrm{PuO}_{2}(\mathrm{OH})_{2}+\mathrm{H}_{2} \mathrm{O}=\mathrm{PuO}_{2}(\mathrm{OH})_{3}^{-}+\mathrm{H}^{+} ; \mathrm{K}=(2)\left(10^{-10}\right)(\text { Reference 6) }
\end{aligned}
$$

Figure 7 (and Figure 8, which is an expansion of the upper left corner of Figure 7) raises many questions. For example: what is the location of polymeric tetravalent plutonium in Figure 7.

To some degree, Figure 2 and Figure 7 complement one another. That is, while tetravalent plutonium will precipitate in solutions of low acidity, the diagram of Figure 2 may be used to approximate the behavior of that plutonium which remains unprecipitated.

Calculationsof the type used to prepare Figure 7 may have practical application. For example, suppose it is desired to perform experiments on a plutonium solution in which the soluble plutonium is to be $10^{-3} \mathrm{M}$ and such that the concentration of pentavalent plutonium is to be as high as possible. In what acidity should the pentavalent plutonium be prepared? Figure 9 shows how the solution acidity might be selected. Line A indicates the maximum permissible relative concentration of pentavalent plutonium ${ }^{4} 10$ where $\mathrm{Pu}(\mathrm{V})$ is subject to disproportionation by reaction with acid. Line $B$ represents the maximum relative concentration of pentavalent plutonium in solutions of sufficiently low acid to induce the precipitation of tetravalent plutonium by Equation (46) for which

$$
\mathrm{K}=10^{3 \cdot 16}=\frac{\mathrm{Pu}(\mathrm{VI})}{[\mathrm{Pu}(\mathrm{V})]^{2}}
$$

Since

$$
\mathrm{Pu}(\mathrm{VI})+\mathrm{Pu}(\mathrm{V})=10^{-\mathrm{a}}
$$

it follows that $\mathrm{Pu}(\mathrm{V})$ is approximately $23 \%$ of the soluble plutonium present. Line $\mathrm{C}$ represents the maximum relative amount of $\mathrm{Pu}(\mathrm{V})$ permissible under conditions of more extensive hydrolysis, i.e., Equation (47), for which

$$
\mathrm{K}=10^{26 \cdot 14}=\frac{1}{[\mathrm{Pu}(\mathrm{V})]^{2}\left[\mathrm{OH}^{-}\right]^{2}}
$$

or

$$
\operatorname{Pu}(V)=\left[\frac{\left[\mathrm{H}^{+}\right]^{2}}{\left[\mathrm{~K}_{\mathrm{W}}\right]^{2}\left[10^{26 \cdot 14}\right]}\right]^{\frac{1}{2}}=8.5\left[\mathrm{H}^{+}\right]
$$


Hence, the acid region of choice, within the accuracy of the data, is $\mathrm{pH}$ 1.5 to $\mathrm{pH}$ 3.5. This agrees with experience. Experience indicates, however, that greater kinetic stability may be achieved near pH 4 . Hence, the preparation of $100 \% \mathrm{Pu}(\mathrm{V})$ solutions (which are not at equilibrium) may be preferably prepared at a higher $\mathrm{pH}$ (for example, in a pyridinepyridinium nitrate buffer) ${ }^{15}$ than indicated by Figure 9.

The position of line 10 in Figure 7 should be regarded as speculative. The nature of the alkali soluble $\mathrm{Pu}(\mathrm{VI})$ species is not well understood. 19 It may be $\left[\mathrm{PuO}_{2}(\mathrm{OH})_{3}\right]_{3} \mathrm{OH}^{-}$. Line 4 may change slope when it intersects a line such as Line 10 representing the amphoterism of $\mathrm{Pu}(\mathrm{VI})$, but the locus of slope change, and the new valve of the slope, depends upon the solubility product of the solubilized $\mathrm{Pu}(\mathrm{VI})$ species as well as its composition.

A general statement of charge conservation useful in the study of plutonium solutions is

$$
(3-N) W+(4-N) X+(5-N) Y+(6-N) Z=0
$$

This equation may be derived from the statement of average oxidation number, Equation (2). 


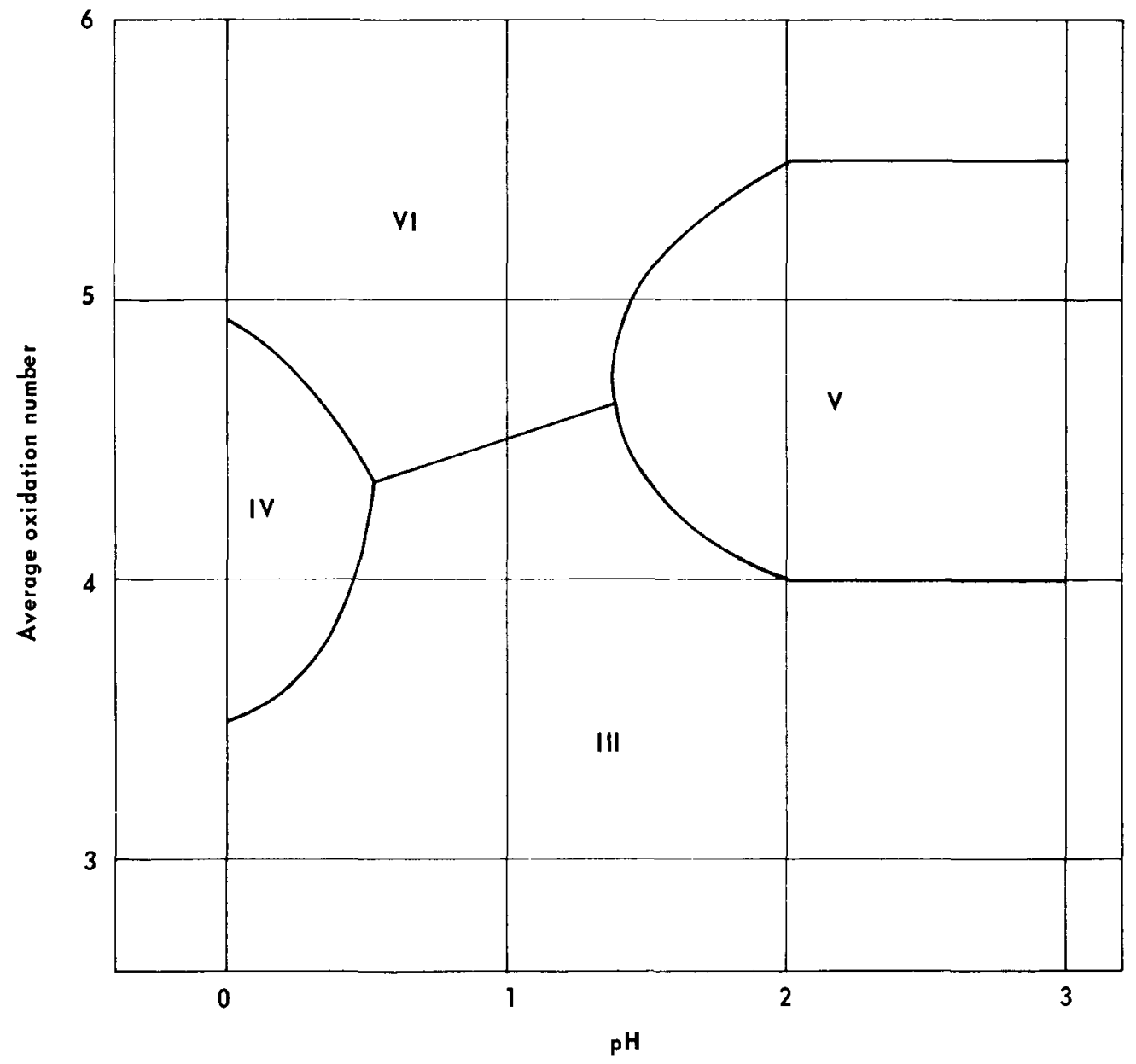

FIGURE 1 - Approximate nonlinear plutonium predominance region diagram (hydrolysis neglected). 


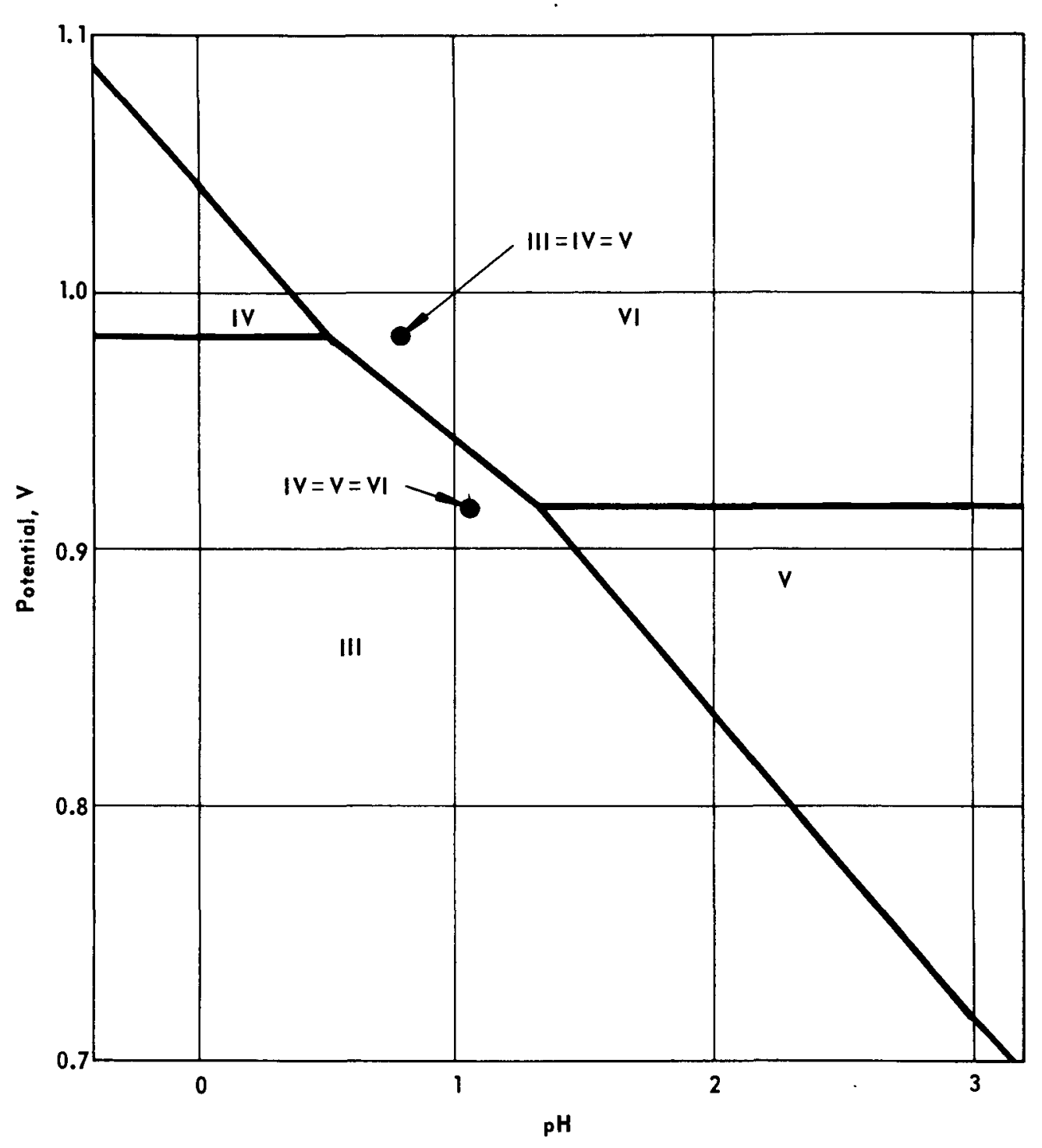

FIGURE 2 - Linear predominance region diagram for plutonium (hydrolysis neglected). 


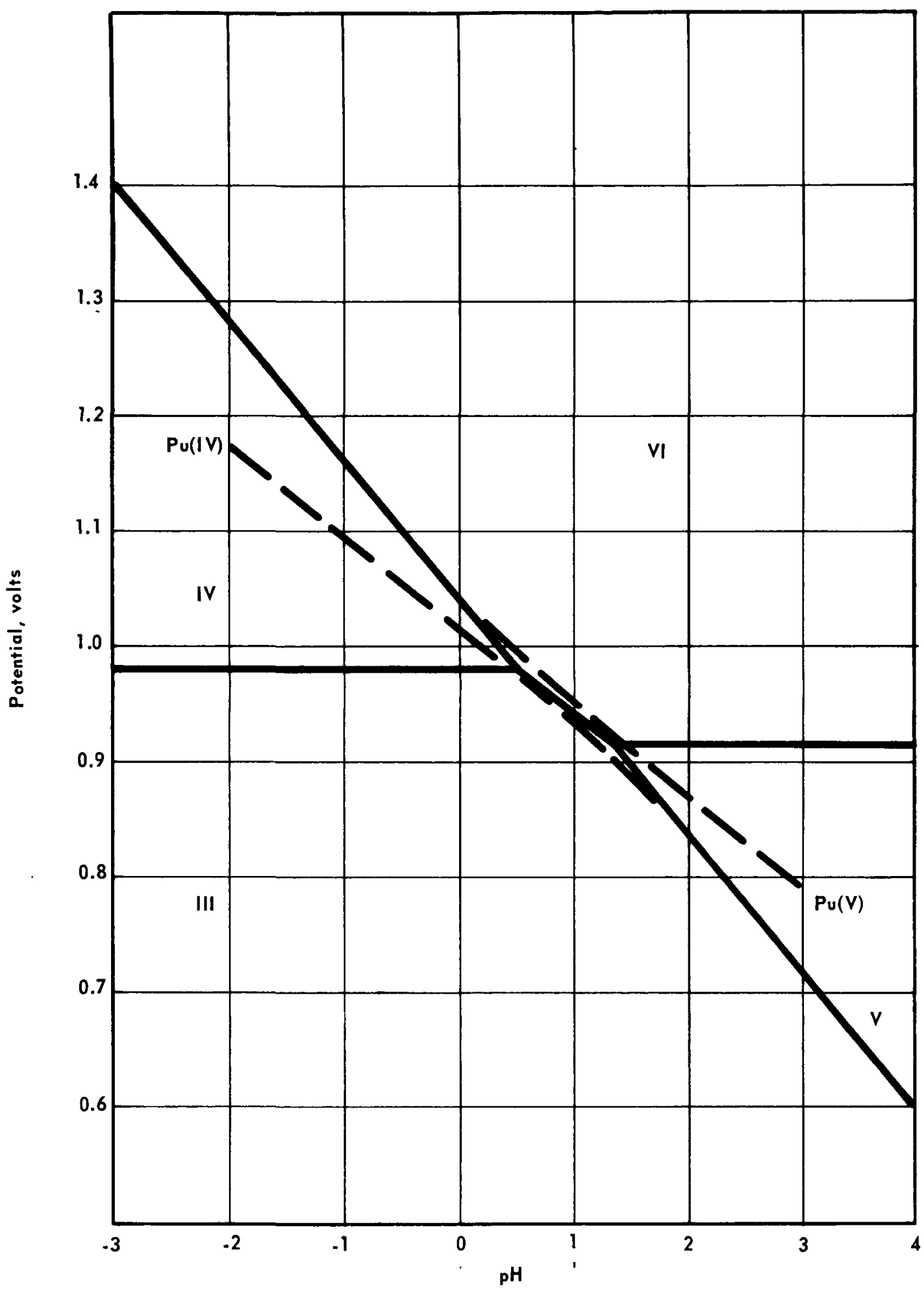

FIGURE 3 - Paths of disproportionation for tetravalent and pentavalent plutonium (hydrolys is neglected). 


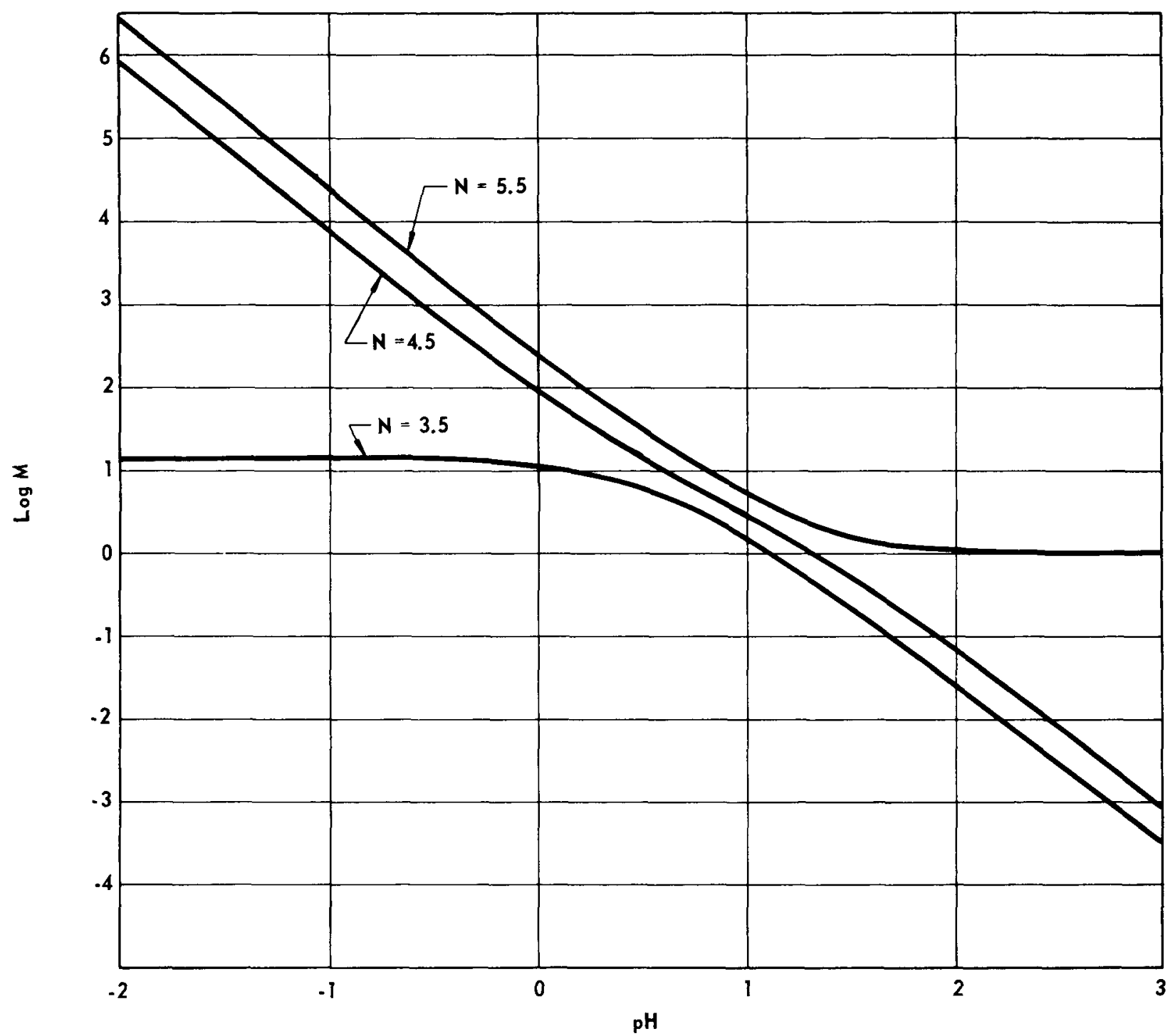

FIGURE 4 - Behavior of some oxistatic ratios with acidity (hydrolysis neglected). 


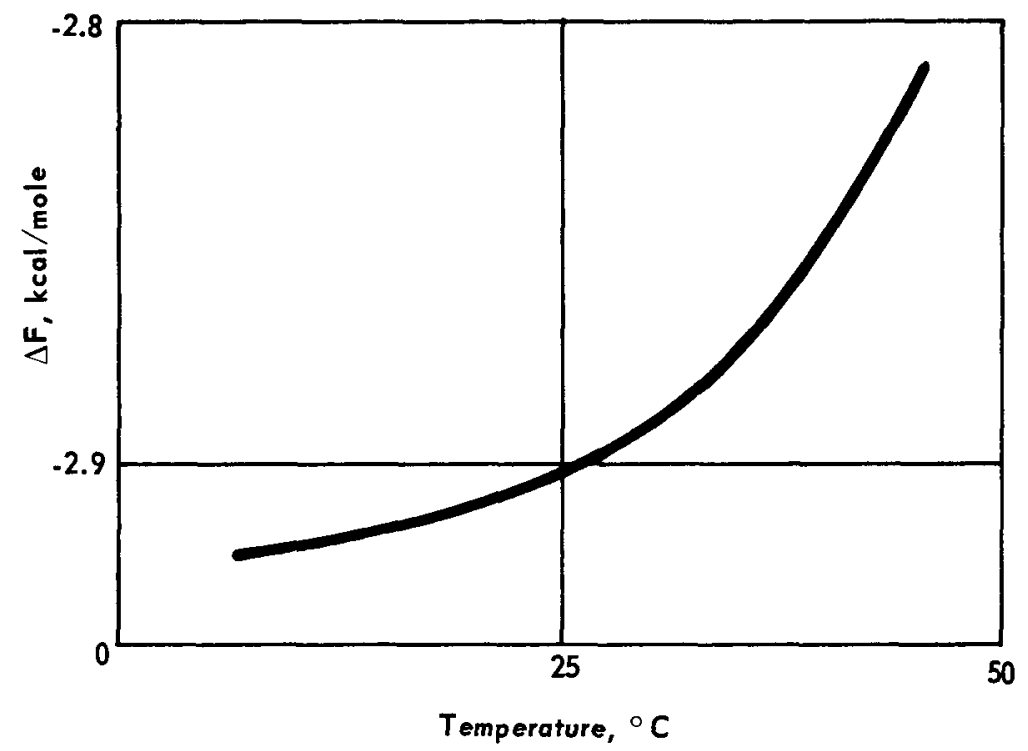

FIGURE 5 - Proposed free energy change for the disproportionation of Pu(V) as a function of temperature (molar hydrochloric acid; hydrolysis neglected).

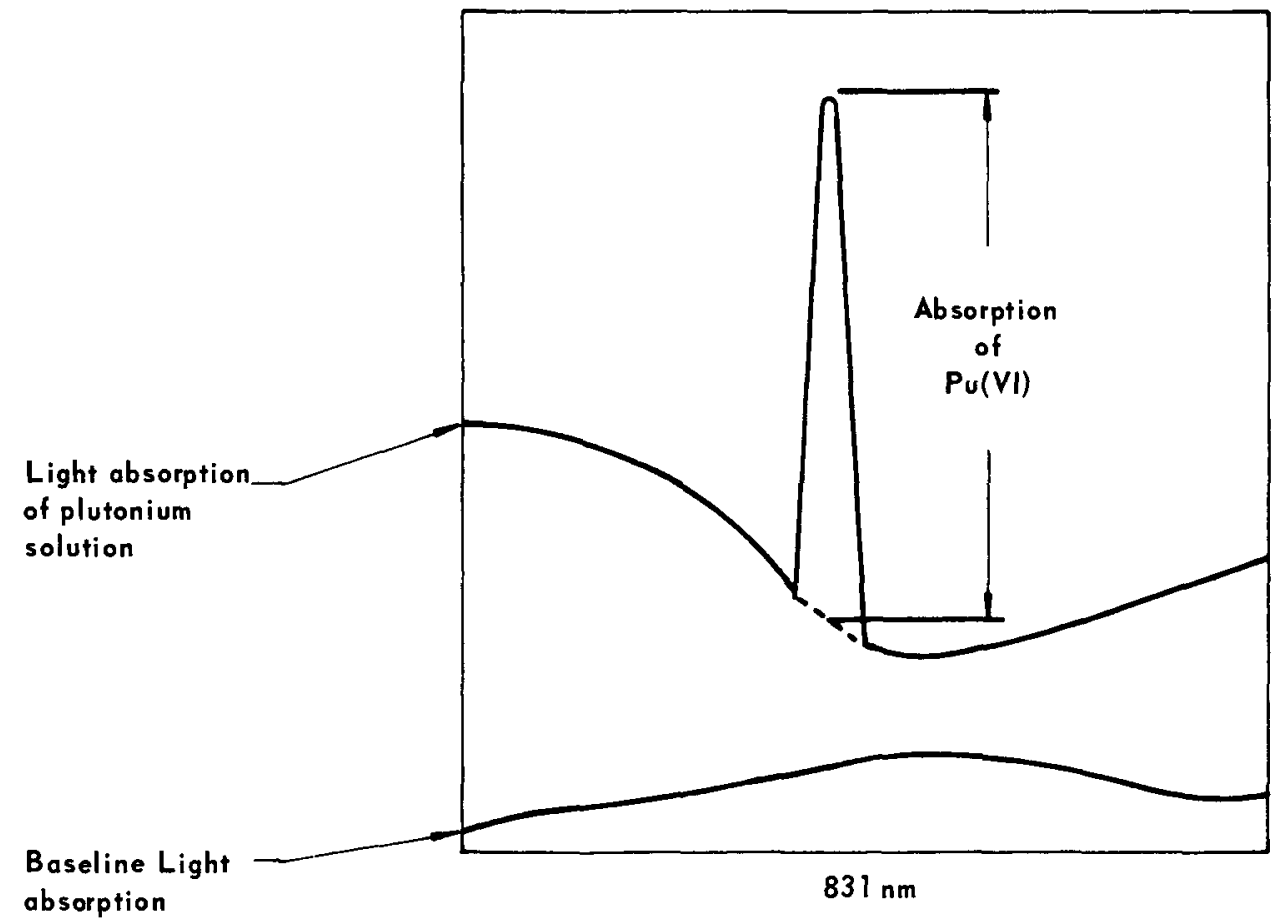

FIGURE 6 - Spectrophotometric method of estimating the concentration of hexavalent plutonium. 


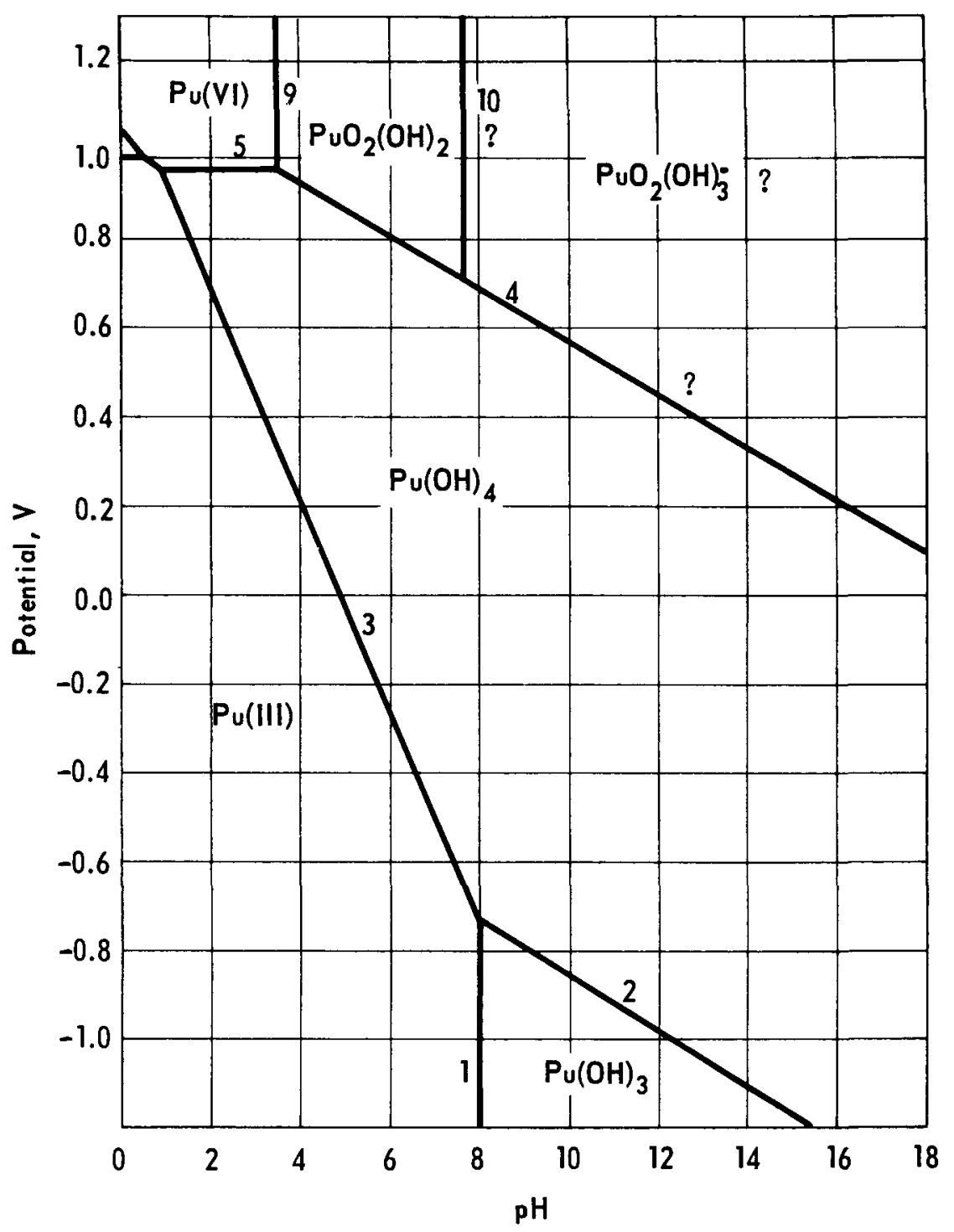

FIGURE 7 - Predominance region diagram for plutonium including hydrous oxides. 


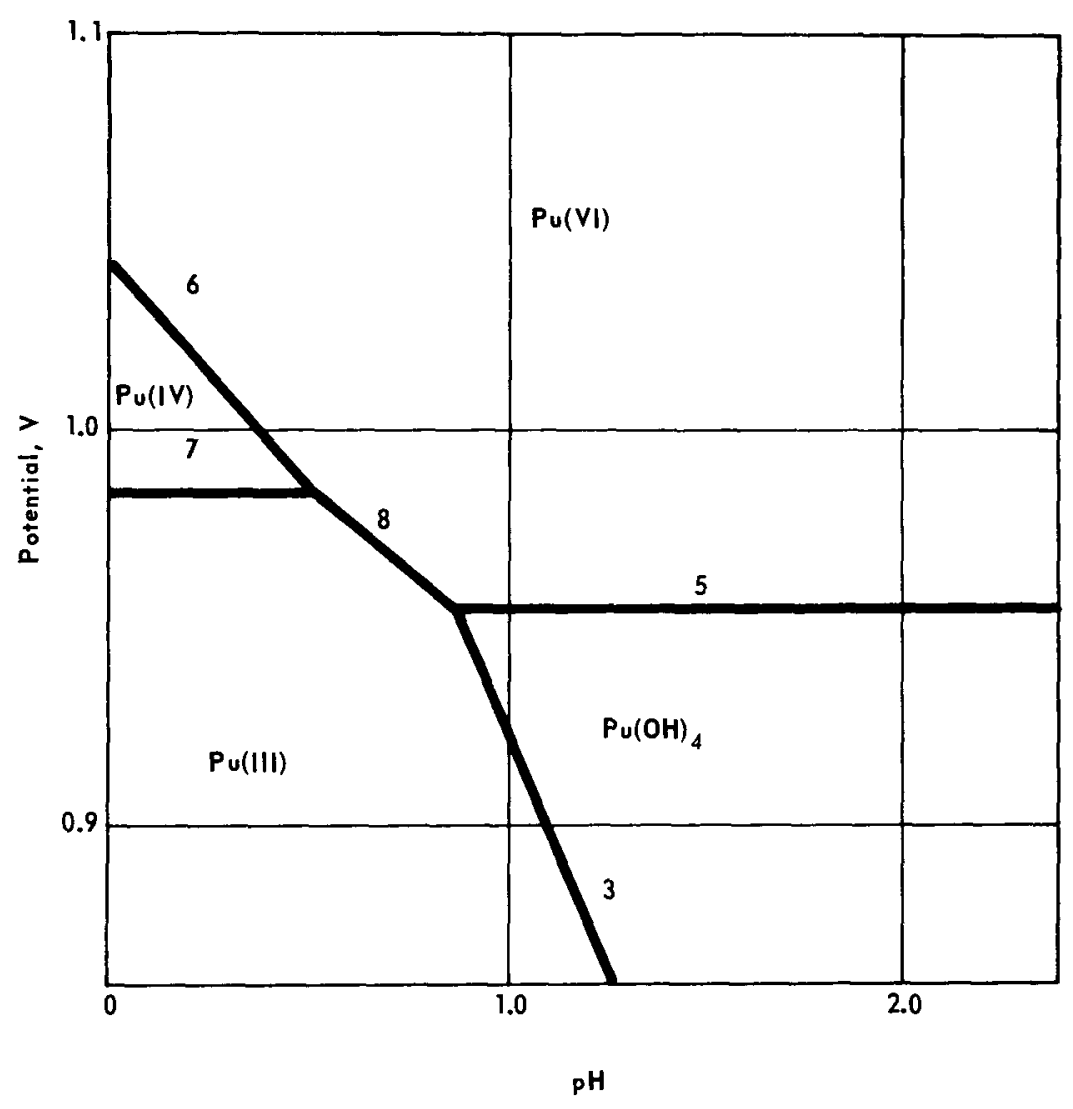

FIGURE 8 - Expansion of upper left portion of Figure 7. 


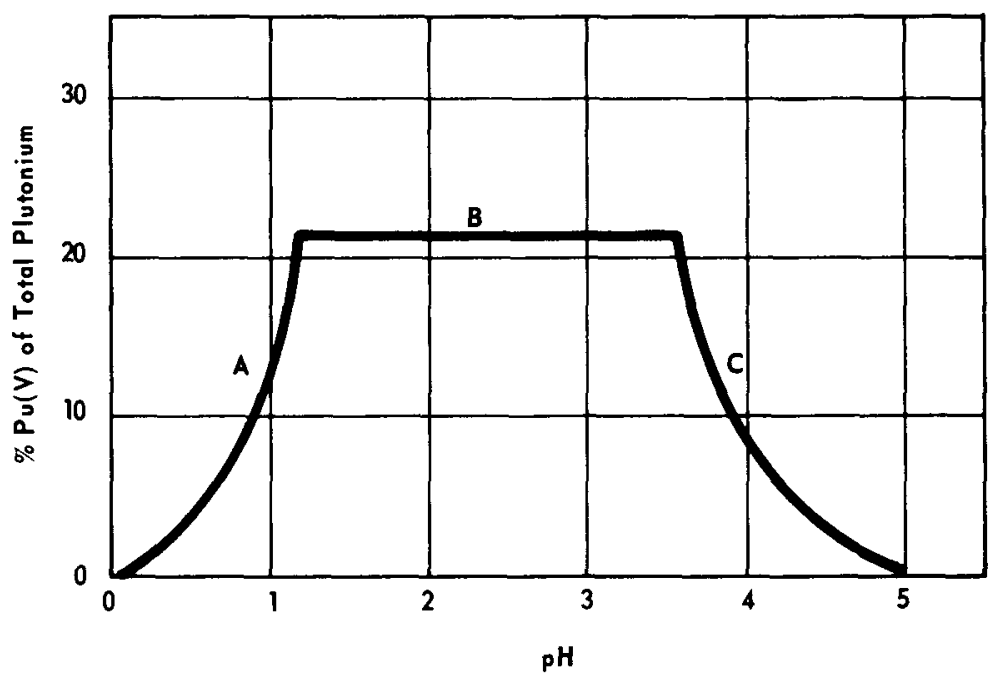

FIGURE 9 - Method of estimating optimum acidity range for preparing pentavalent plutonium.

M. F. Hauenstein, editor 